\section{SANDIA REPORT}

SAND96-2302 • UC-2010

Unlimited Release

Printed September 1996
RECEIVED

OCT 231996

OSTI

\title{
Autonomous Gas Chromatograph System for Thermal Enhanced Vapor Extraction System (TEVES) Proof of Concept Demonstration
}

Frank J. Peter, George R. Laguna

Prepared by

Sandia National Laboratories

Albuquerque, New Mexico 87185 and Livermore, California 94550

for the United States Department of Energy

under Contract DE-AC04-94AL85000

\section{Approved for public release; djstribution is unlimited.}
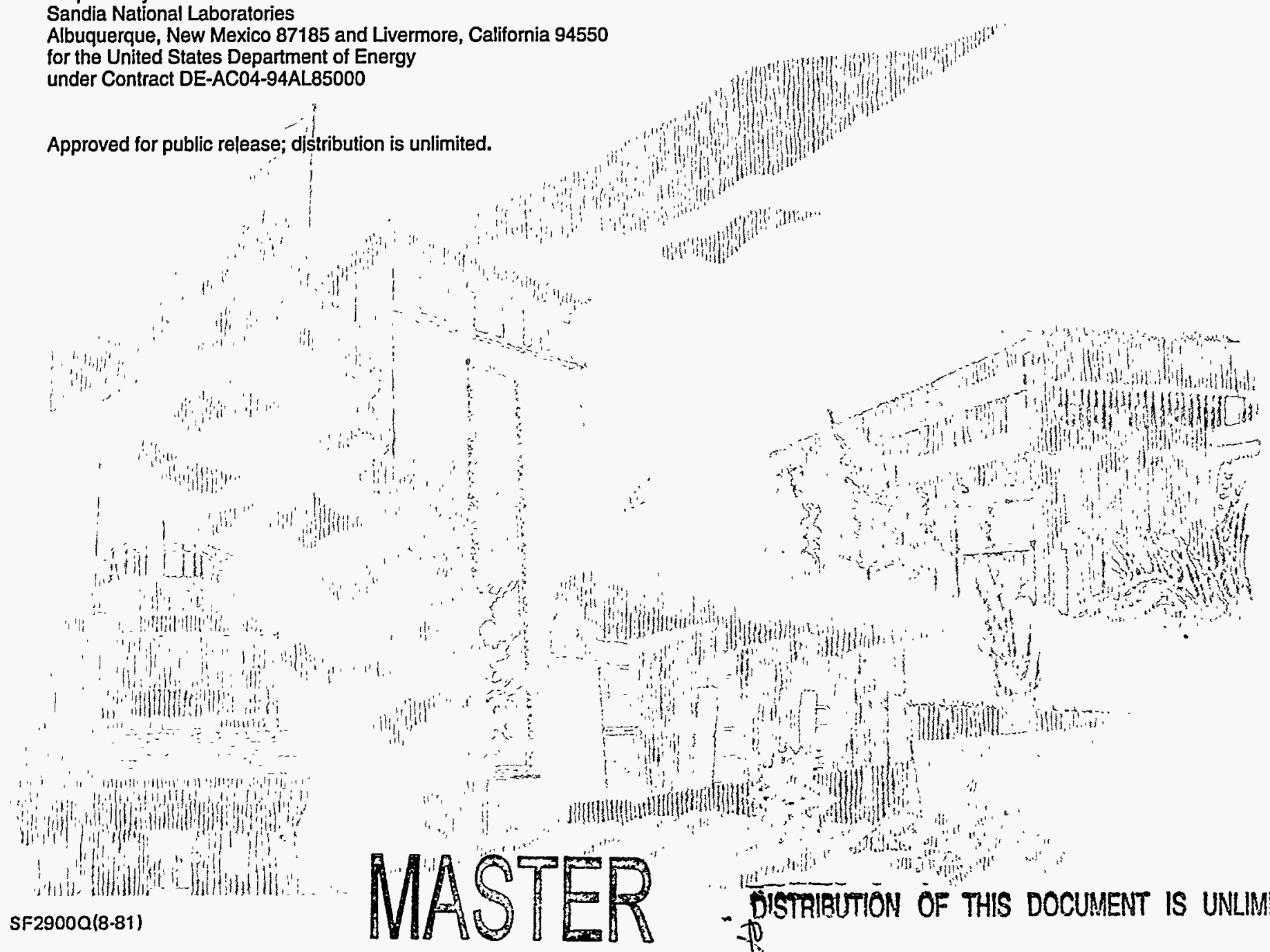
Issued by Sandia National Laboratories, operated for the United States Department of Energy by Sandia Corporation.

NOTICE: This report was prepared as an account of work sponsored by an agency of the United States Government. Neither the United States Government nor any agency thereof, nor any of their employees, nor any of their contractors, subcontractors, or their employees, makes any warranty, express or implied, or assumes any legal liability or responsibility for the accuracy, completeness, or usefulness of any information, apparatus, product, or process disclosed, or represents that its use would not infringe privately owned rights. Reference herein to any specific commercial product, process, or service by trade name, trademark, manufacturer, or otherwise, does not necessarily constitute or imply its endorsement, recommendation, or favoring by the United States Government, any agency thereof or any of their contractors or subcontractors. The views and opinions expressed herein do not necessarily state or reflect those of the United States Government, any agency thereof or any of their contractors.

Printed in the United States of America. This report has been reproduced directly from the best available copy.

Available to $\mathrm{DOE}$ and $\mathrm{DOE}$ contractors from

Office of Scientific and Technical Information

PO Box 62

Oak Ridge, TN 37831

Prices available from (615) 576-8401, FTS 626-8401

Available to the public from

National Technical Information Service

US Department of Commerce

5285 Port Royal Rd

Springfield, VA 22161

NTIS price codes

Printed copy: A04

Microfiche copy: A01 
SAND 96-2302

Distribution

Unlimited Release

Printed September 1996

Category UC-2010

\title{
Autonomous Gas Chromatograph System for Thermal Enhanced Vapor Extraction System (TEVES) Proof of Concept Demonstration
}

\author{
Frank J. Peter, George R. Laguna \\ Manufacturing Control Subsystems Department 2338 \\ Sandia National Laboratories \\ Albuquerque, NM 87185
}

\begin{abstract}
An autonomous gas chromatograph system was designed and built to support the Thermal Enhanced Vapor Extraction System (TEVES) demonstration. TEVES is a remediation demonstration that seeks to enhance an existing technology (vacuum extraction) by adding a new technology (soil heating). A pilot scale unit was set up at one of the organic waste disposal pits at the Sandia National Laboratories Chemical Waste Landfill (CWL) in Tech Area III. The responsibility for engineering a major part of the process instrumentation for TEVES belonged to the Manufacturing Control Subsystems Department. The primary mission of the one-of-kind hardware/software system is to perform on-site gas sampling and analysis to quantify a variety of volatile organic compounds (VOCs) from various sources during TEVES operations. The secondary mission is to monitor a variety of TEVES process physical parameters such as extraction manifold temperature, pressure, humidity, and flow rate, and various subsurface pressures. The system began operation in September 1994 and was still in use on follow-on projects when this report was published.
\end{abstract}




\section{Table of Contents}

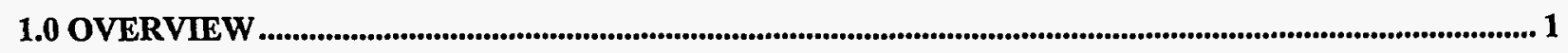

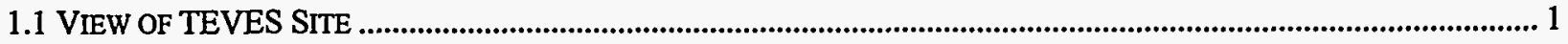

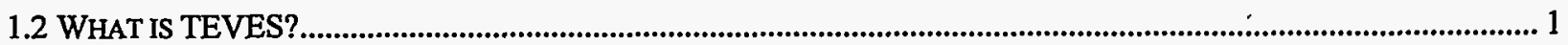

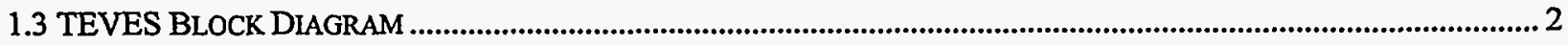

1.4 MANUFACTURING CONTROL SUBSYSTEMS DEPARTMENT CONTRIBUTION............................................................ 2

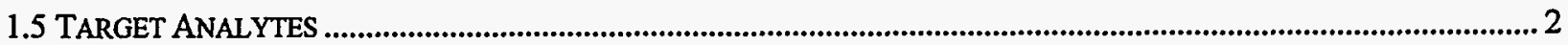

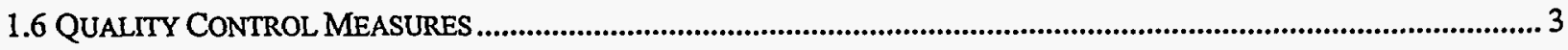

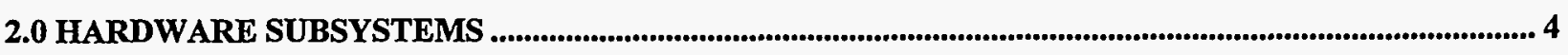

2.0.1 View of Autonomous GC inside Lab building ........................................................................................... 4

2.0.1 Hardware Subsystem Block Diagram ......................................................................................................... 5

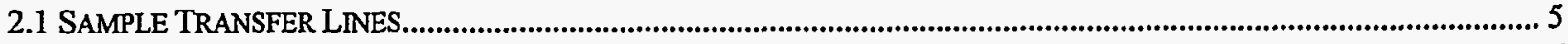

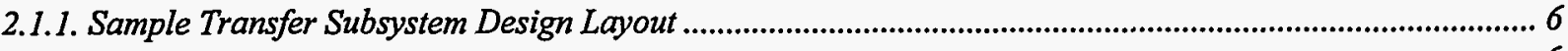

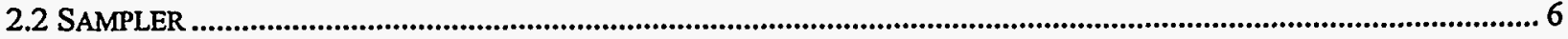

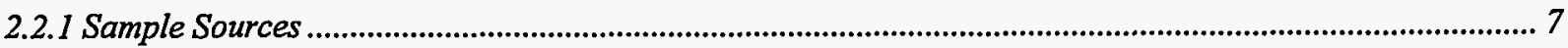

2.2.2 Sampler Design Layout ................................................................................................................................. 7

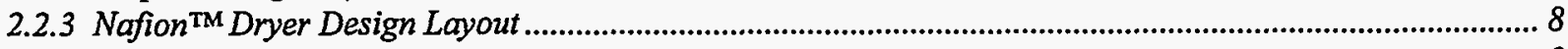

2.2.4 Sample Loop Volume................................................................................................................................... 8

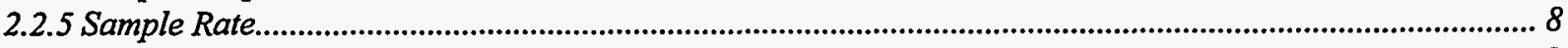

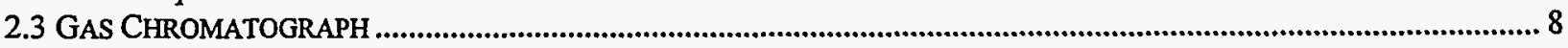

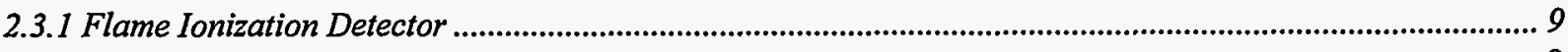

2.4 EXTRACTION MANIFOLD AND SUBSURFACE PRESSURE INSTRUMENTATION.............................................................. 9

2.4.1 Extraction Manifold \& Subsurface Pressure Instrumentation .......................................................................... 9

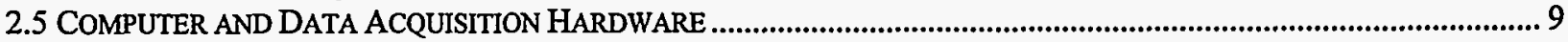

2.5.1 Computer \& Data Acquisition Hardware Block Diagram .................................................................................. 10

2.5.2 Computer Electrical Interface ........................................................................................................................ 11

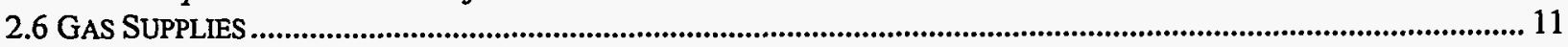

3.0 SUMMARY OF OPERATION ................................................................................................................... 12

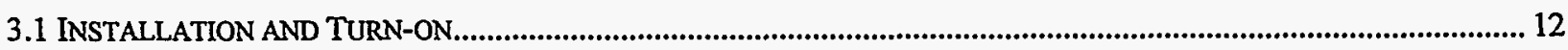

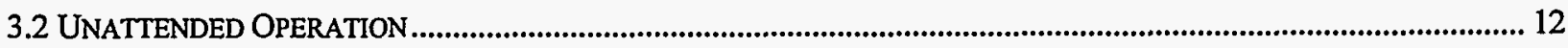

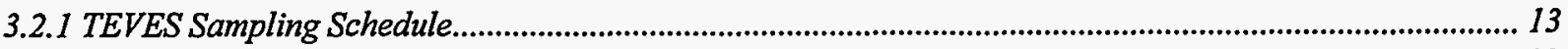

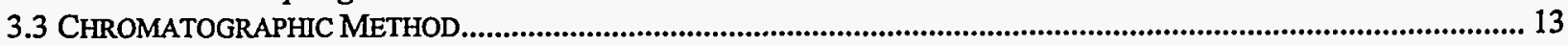

3.3.1 Column Oven Temperature Profile ......................................................................................................... 14

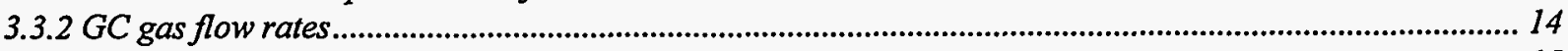

3.3.3 GC Results............................................................................................................................................ 15

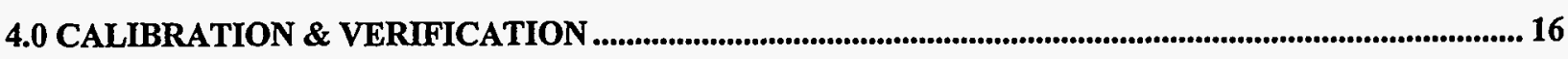

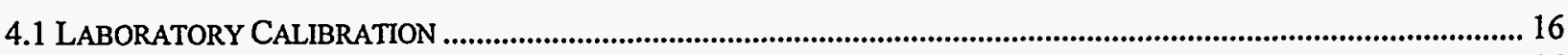

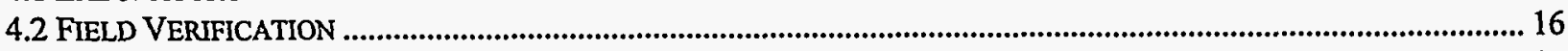

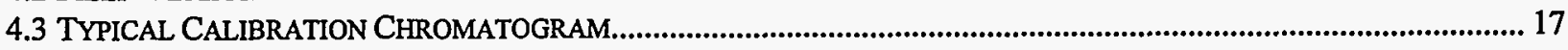

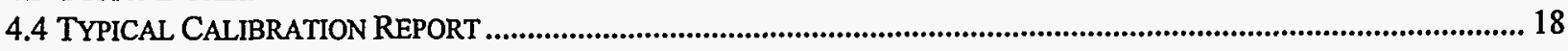

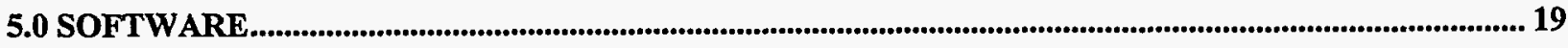

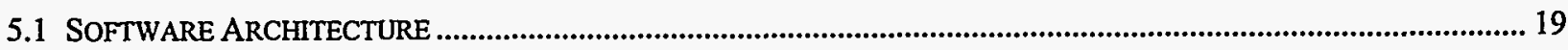

5.1.1 Labview Virtual Instruments .................................................................................................................... 19

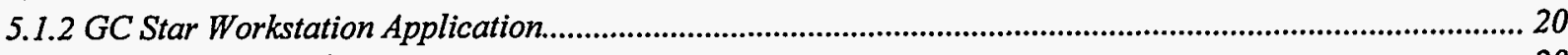

5.1.3 Visual Basic Applications............................................................................................................................... 20

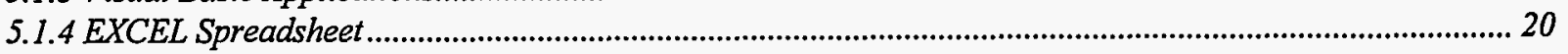




\section{DISCLAIMER}

Portions of this document may be illegible in electronic image products. Images are produced from the best available original document. 


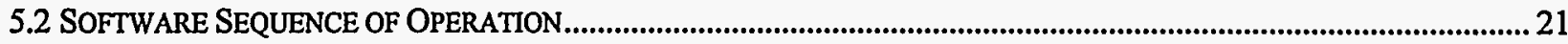

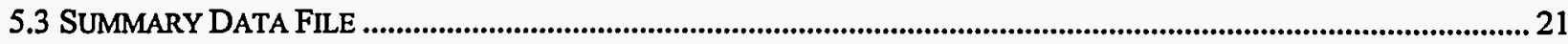

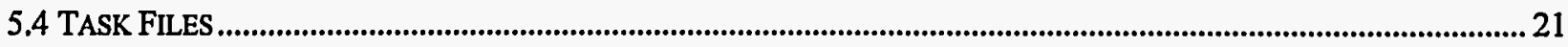

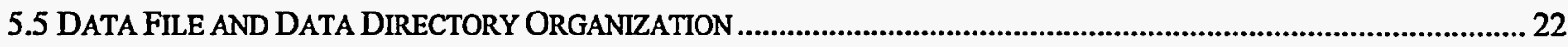

6.0 LESSONS LEARNED, PROPOSED SYSTEM IMPROVEMENTS ........................................................... 23

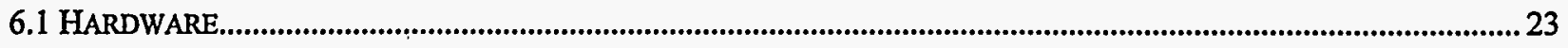

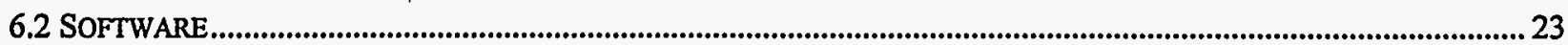

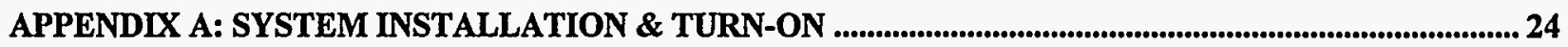

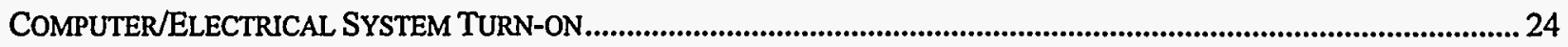

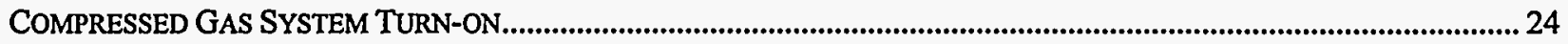

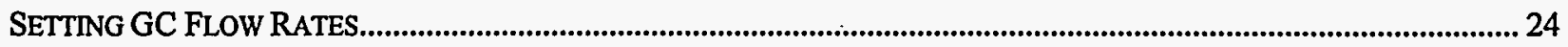

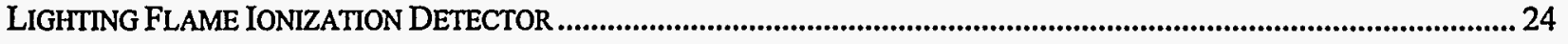

APPENDIX B: GAS SUPPLY HOOKUPS (BACK PANEL OF GC) .................................................................. 25

APPENDIX C: COMPRESSED GAS ASSEMBLY DIAGRAMS ....................................................................... 26

HELIUM

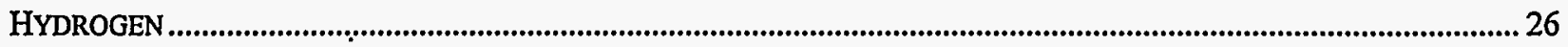

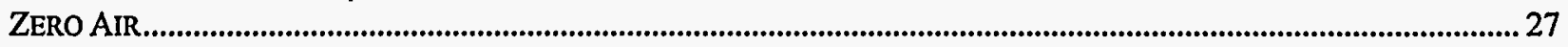

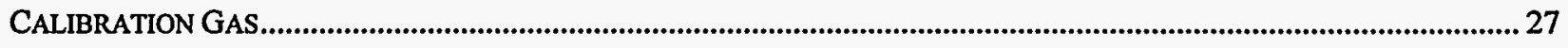

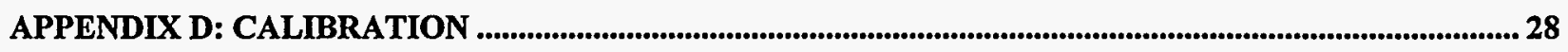

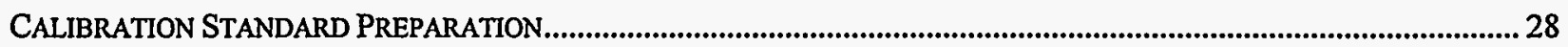

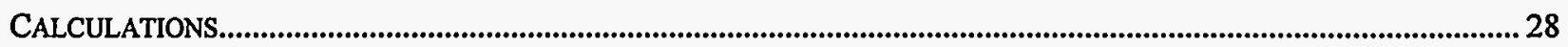

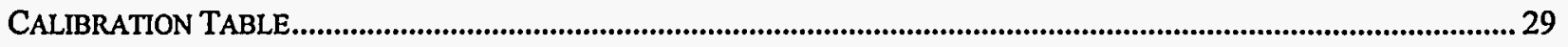

APPENDIX E: CALIBRATION STANDARD CERTIFICATE OF ANALYSIS ................................................ 30

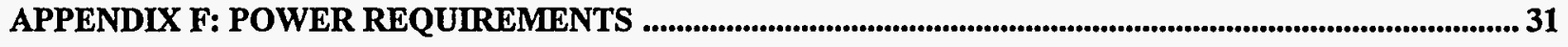

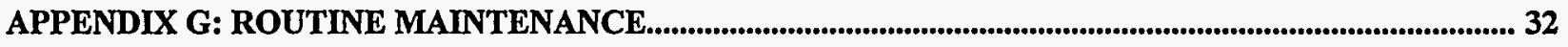

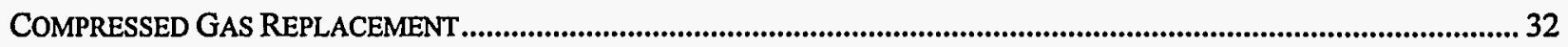

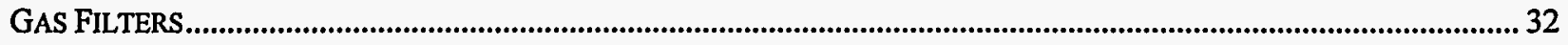

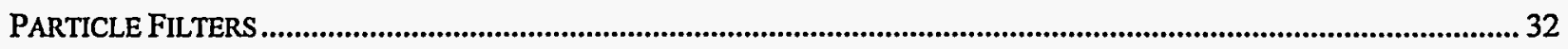

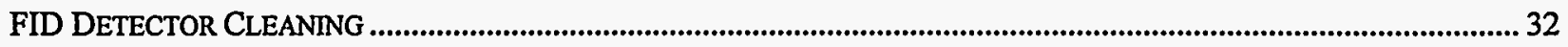

APPENDIX H: MANIFOLD AIR FLOW RATE CALCULATIONS ................................................................... 33

APPENDIX I: VOC MASS REMOVAL RATE CALCULATIONS .......................................................................... 34

APPENDIX J: WATER MASS REMOVAL RATE CALCULATIONS ................................................................... 35

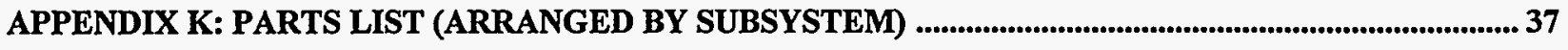

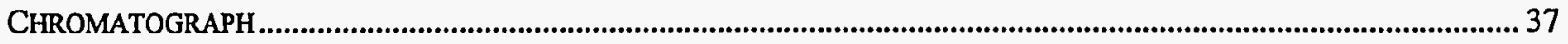

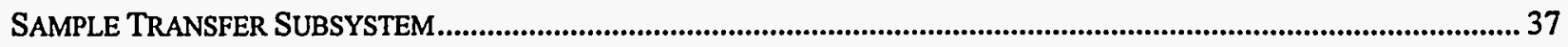

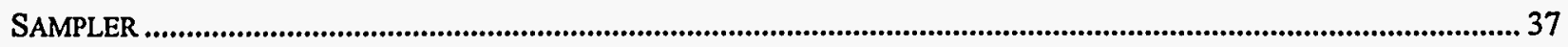

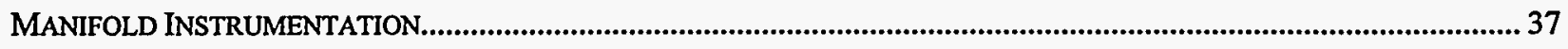

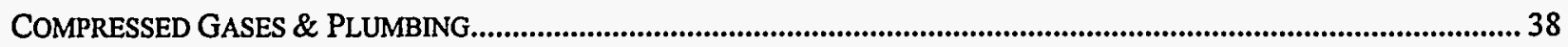

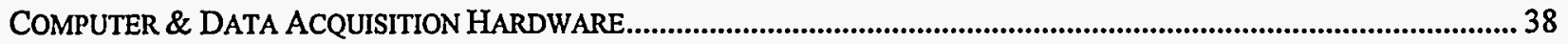




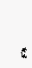




\subsection{Overview}

Department 2338 has developed an autonomous gas chromatograph system for Department 6621 to support the Thermal Enhanced Vapor Extraction System (TEVES) experiment. The primary mission of this one-of-kind hardware/software system is to perform on-site gas sampling and analysis to quantify a variety of volatile organic compounds (VOCs) from various sources during TEVES operations. The secondary mission is to monitor a variety of TEVES process physical parameters such as extraction manifold temperature, pressure, humidity, and flow rate, and various subsurface pressures. The system is located in a portable, temperature-controlled building at the chemical waste landfill in Area III and was in continuous operation from September 1994 through June 1995.

\subsection{View of TEVES Site}

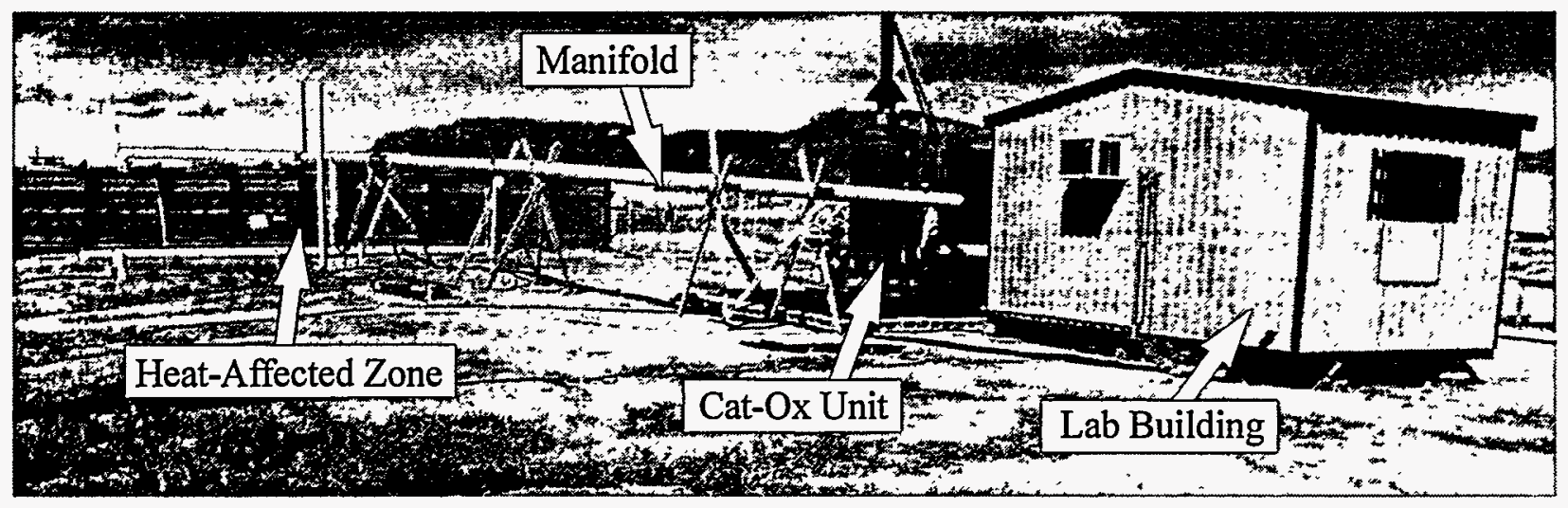

\subsection{What is TEVES?}

The Thermal Enhanced Vapor Extraction System (TEVES) is a demonstration that seeks to enhance an existing technology (vacuum extraction) by adding a new technology (soil heating). A pilot scale unit was set up at one of the organic waste disposal pits at the Sandia National Laboratories Chemical Waste Landfill (CWL) in Tech Area III. A vacuum blower pulls untreated vapors from the ground via two boreholes into an extraction manifold. The vapors (containing air, a complex mix of volatile organic compounds and water) are dried and then introduced into a catalytic oxidation (cat-ox) unit which converts the vapors into water, carbon dioxide, and simple acids. The treated vapors, rendered non-hazardous are vented into the ambient air. A more detailed description may be found in:

Resource Conservation and Recovery Act, Research Development, and Demonstration Permit for Thermal Enhanced Vapor Extraction System. issued by the New Mexico Environment Department, Santa Fe, New Mexico, May 26, 1994. 


\subsection{TEVES Block Diagram}

\section{landfill area affected}

by heat \& vacuum

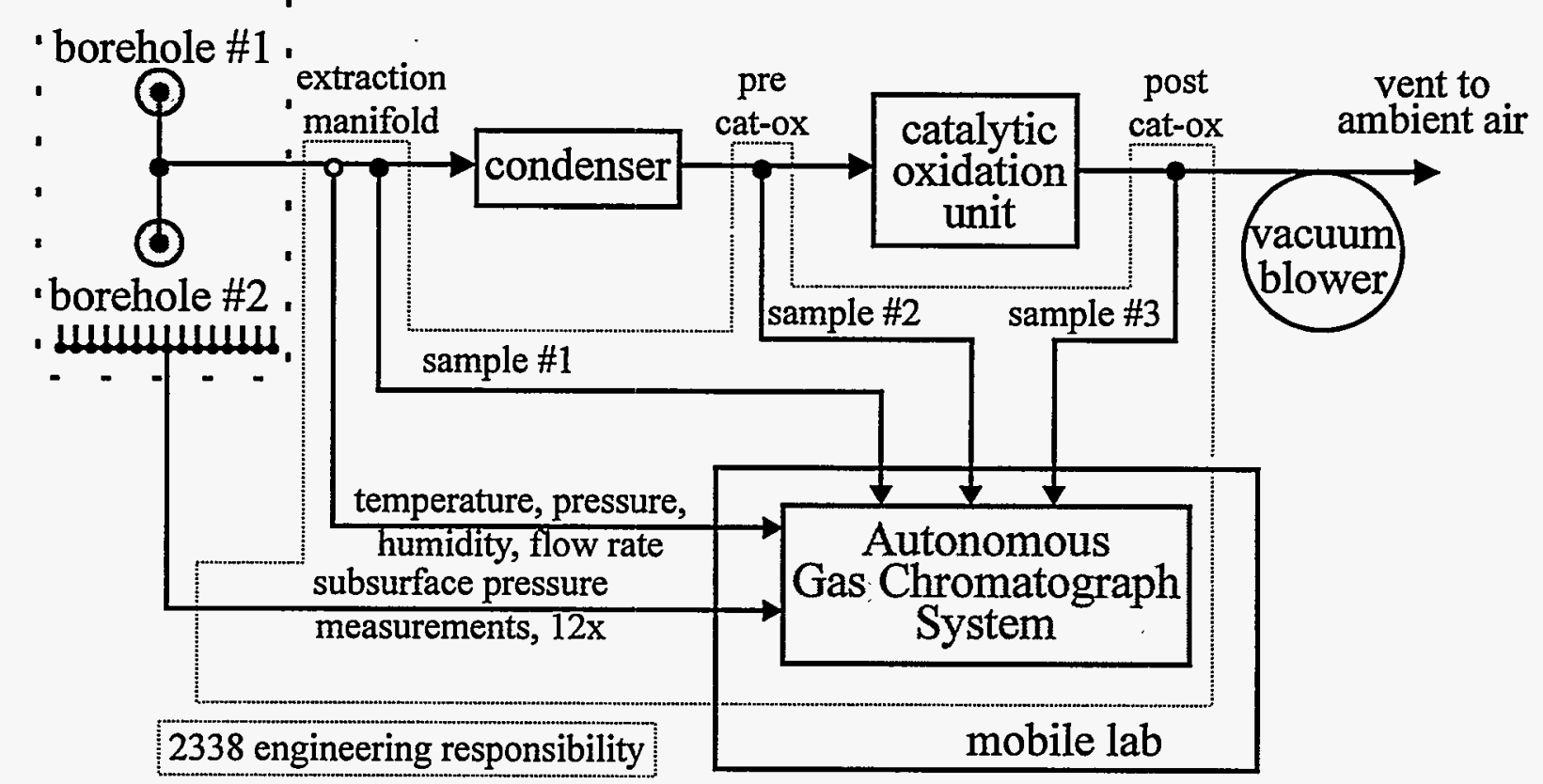

\subsection{Manufacturing Control Subsystems Department Contribution}

The mission of the autonomous GC system is to collect data to help characterize several aspects of the TEVES experiment. These include:

- VOC concentrations in the untreated borehole effluent

- extraction manifold flow rate

- extraction manifold temperature, pressure, and relative humidity

- mass removal rates for a select list of VOCs

- mass removal rates for water

- efficiency of the catalytic oxidation system

- mass discharge rates of VOCs into the ambient air

- subsurface pressure profile.

\subsection{Target Analytes}

The gas chromatograph method quantifies the following compounds with nominal detection limits ranging from $2 \mathrm{ppm}$ to $1,000 \mathrm{ppm}$ calibrated, but with the capability to extend lower and higher. 


\begin{tabular}{|l|c|}
\hline Compound & CAS No. \\
\hline Dichlorobenzene (1,2-) & $95-50-1$ \\
\hline Ethyl Benzene & $100-41-4$ \\
\hline Freon 113 & $76-13-1$ \\
\hline Pentane & $109-66-0$ \\
\hline Tetrachloroethylene (PCE) & $127-18-4$ \\
\hline $1,1,1-$ Trichloroethane (TCA) & $71-55-6$ \\
\hline Trichloroethylene (TCE) & $79-01-6$ \\
\hline Xylene (o- isomer) & $108-38-3$ \\
\hline Xylene (m- isomer) & $95-47-6$ \\
\hline Xylene (p- isomer) & $*$ \\
\hline
\end{tabular}

* m-Xylene \& p-Xylene coelute

\subsection{Quality Control Measures}

The system is operated in accordance with the $\mathrm{QC} / \mathrm{QA}$ requirements described in:

Resource Conservation and Recovery Act, Research Development, and Demonstration Permit for Thermal Enhanced Vapor Extraction System. issued by the New Mexico Environment Department, Santa Fe, New Mexico, May 26, 1994.

To this end the following were incorporated:

- twice daily calibration verification with a NIST-traceable calibration gas

- twice daily zero air certification to establish lower detection limits

- periodic measurement of parameters that impact data quality (mobile lab temperature, gas supply pressures, valve states, sample flow rate). 


\subsection{Hardware Subsystems}

The autonomous GC system consists of six hardware subsystems:

- sample transfer lines

- sampler

- gas chromatograph

- extraction manifold instrumentation

- computer and data acquisition hardware

- gas supplies.

\subsubsection{View of Autonomous GC inside Lab building}

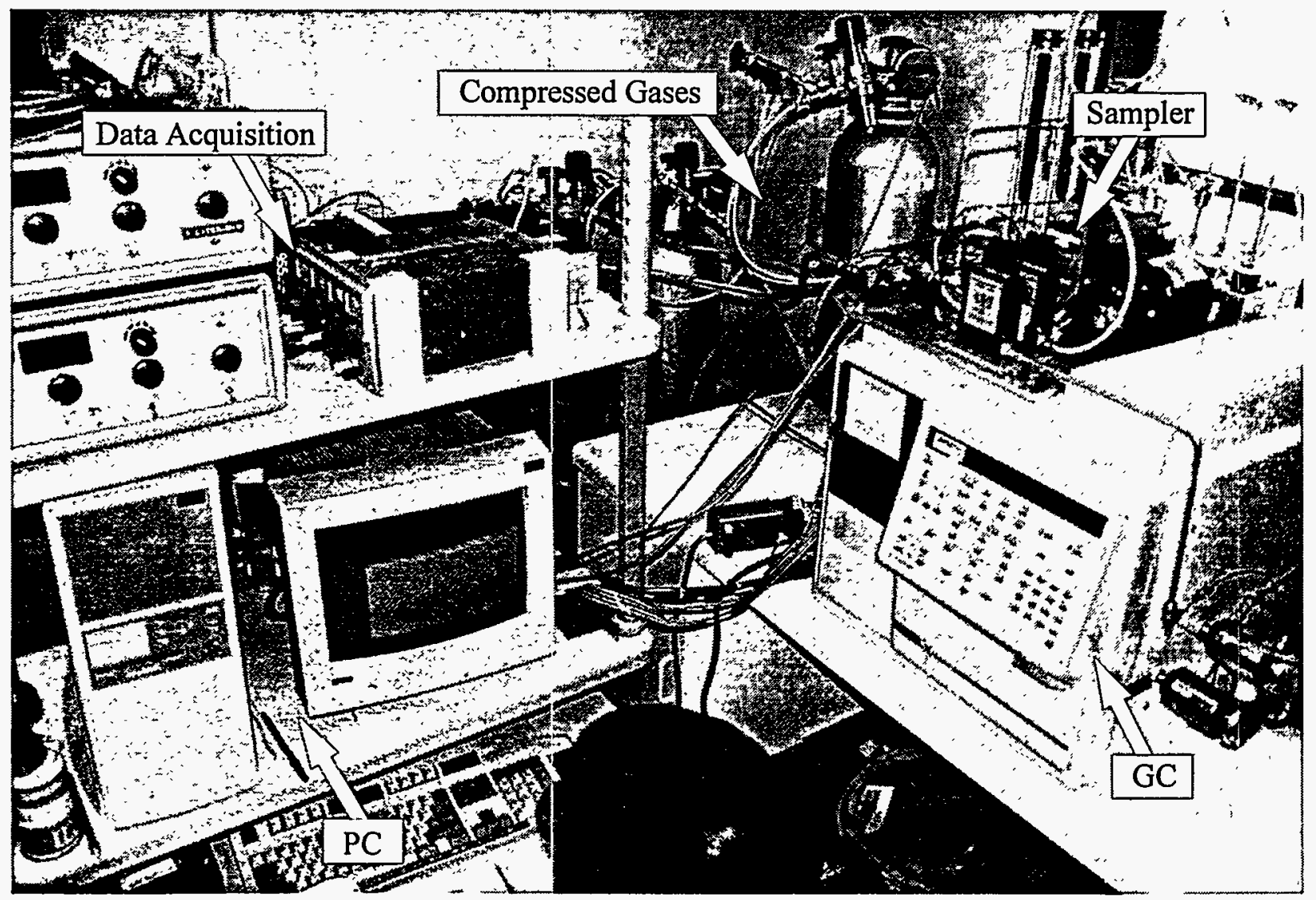




\subsubsection{Hardware Subsystem Block Diagram}

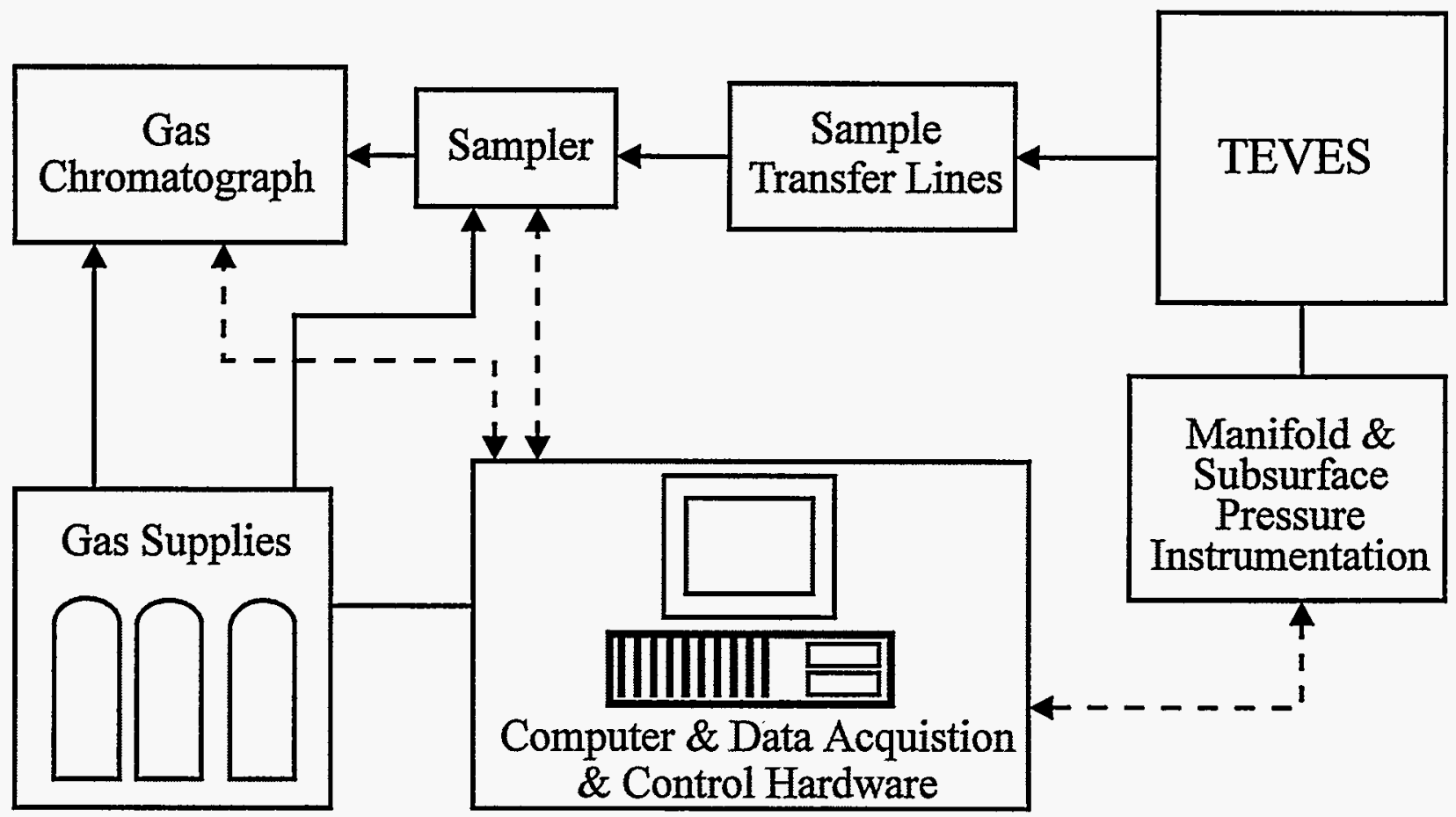

\subsection{Sample Transfer Lines}

The sample transfer lines (Figure 2.1) are designed to deliver a small fraction $(<1 \%)$ of TEVES vapors to the mobile lab where the autonomous GC is located. Three TEVES vapor sources are monitored:

- extraction manifold (untreated borehole effluent)

- pre-cat-ox (dried vapors before catalytic oxidation treatment)

- post-cat-ox (vapors after catalytic oxidation treatment)

Each source has it's own independent transfer subsystem with the following major components:

- heated Teflon ${ }^{\mathrm{TM}}$ tubing

- pump

- particle filter

A tee between the pump and heated lines is the access point for the sampler subsystem. The 25 foot long Teflon ${ }^{\mathrm{TM}}$ lines are heated to $100^{\circ} \mathrm{C}$ to prevent condensation of VOCs and water vapor. The orientation of the components prevents condensation from entering the sampler and fritted filters prevent particulates from entering the sampler subsystem.. The unsampled portion is vented through a charcoal filter to the outside air. 


\subsubsection{Sample Transfer Subsystem Design Layout}

\section{borehole \#1}

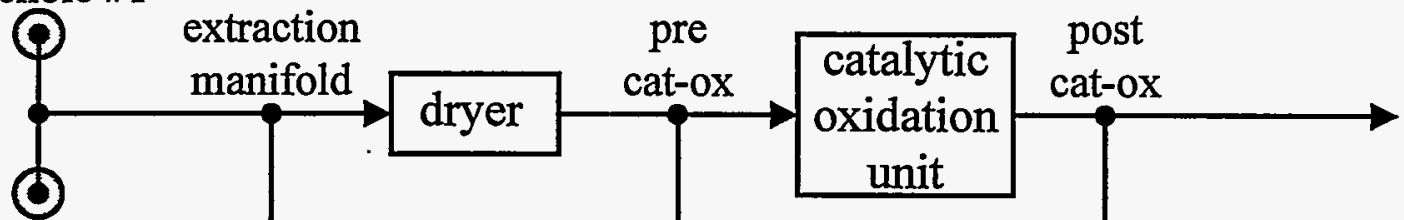

borehole \#2

$90 \mu \mathrm{m}$ filter, $3 \mathrm{x}$

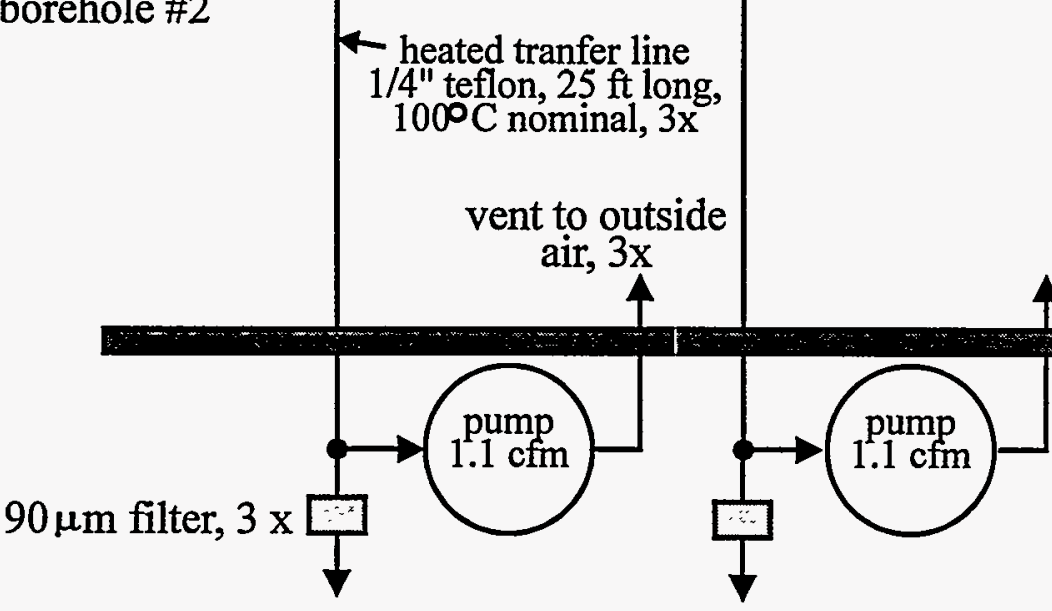

to sampler, $3 \mathrm{x}$

outside of

mobile lab

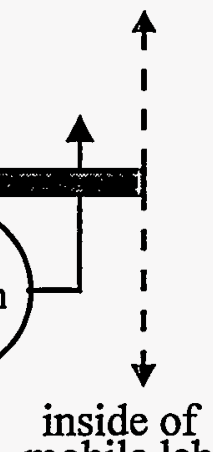

\subsection{Sampler}

The sampler (Figure 2.2) selects the sample source of interest and conditions the sample for injection onto the column. The major components are

- Valco 6 port switching valve

- Nafion ${ }^{\mathrm{TM}}$ dryer

- Tylan FC-260 precision mass flow controller

- rotary vane air pump

- 1 cc sample loop

- 10 port, 2 position injector valve.

The mode of operation is to inject a repeatable volume of sample using constant flow rate sampling through a sample loop. The sample loop volume was carefully selected so that no sample dilution or preconcentration is required to meet the target detection limits for the GC. The sample flow rate was selected to be high enough to eliminate errors due to diffusion effects while keeping pressure drops reasonably low. In addition, a volumetric purge of about $500 \mathrm{x}$ is performed between sample changes to minimize carryover. Because of the extremely high relative humidity of the samples, a Nafion ${ }^{\mathrm{TM}}$ membrane dryer is used for drying all samples upstream of the mass flow controller and sample loop.

The rotary vane pump continuously circulates whichever sample source is selected in order to purge the lines and minimize carryover between runs. The sample source of interest is selected by the six port valve, which diverts the sample stream through the Nafion ${ }^{\mathrm{TM}}$ dryer, mass flow controller, then through a $1 \mathrm{cc}$ sample loop. The mass flow controller regulates flow rate at a 
constant, preset level $(100 \mathrm{cc} / \mathrm{min})$ independent of source pressure. After a 2 minute purge time (a volumetric purge of 200 times), the 10 port valve changes position, injecting the contents of the sample loop (while flow rate is held constant) onto the chromatographic column. After sample injection, the 6 port switching valve is reset to position 1 to purge the sampler with relatively clean room air).

\subsubsection{Sample Sources}

There are five vapor sample sources, three from the TEVES site and two used for quality control.

- extraction manifold (untreated borehole effluent)

- pre-cat-ox (dried vapors before catalytic oxidation treatment)

- post-cat-ox (vapors after catalytic oxidation treatment)

- NIST-traceable calibration verification standard (to monitor GC calibration stability)

- UHP zero air (to establish lower detection limits)

\subsubsection{Sampler Design Layout}

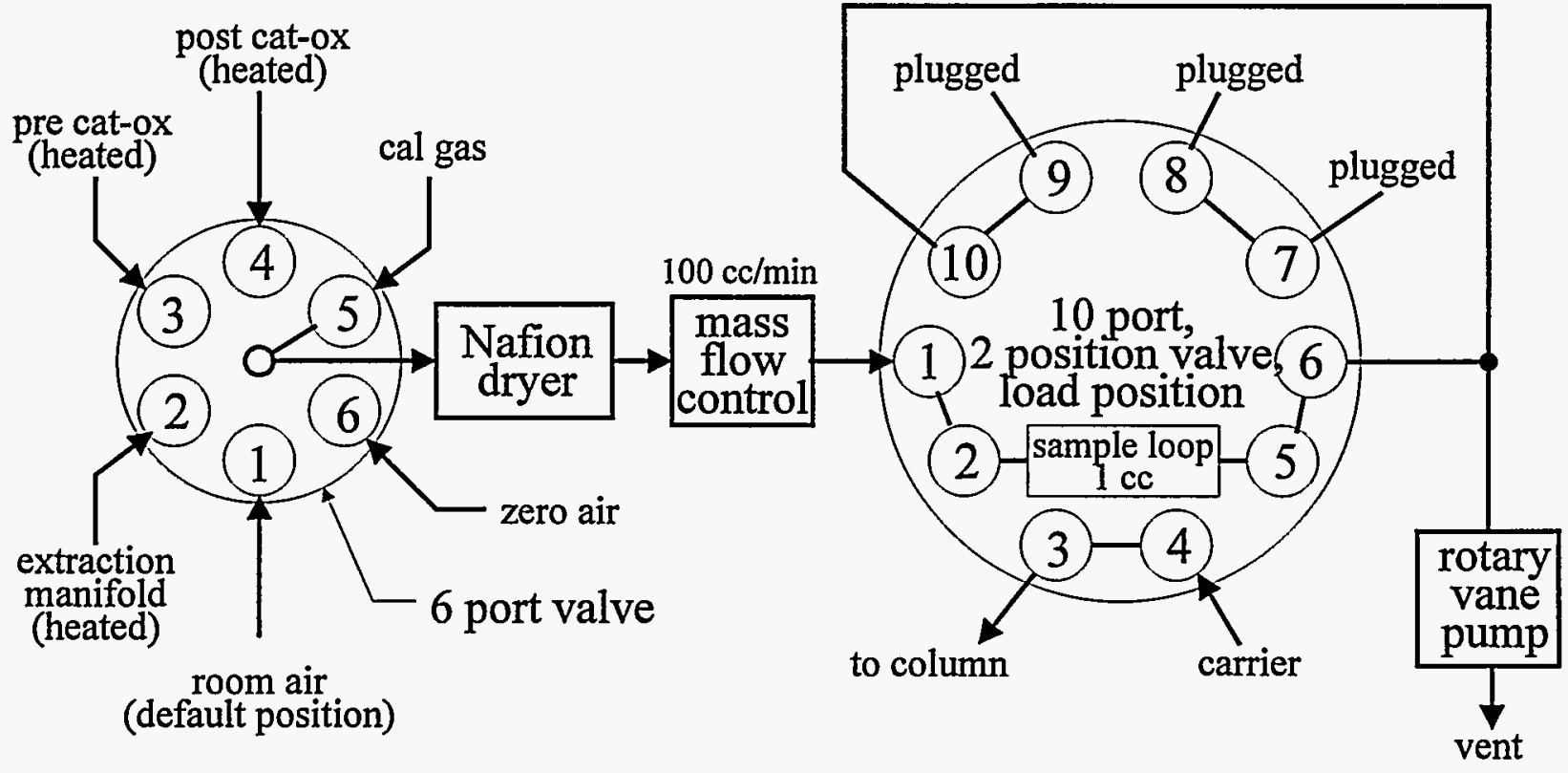

Because of the extremely high relative humidity of the samples, a Nafion ${ }^{\mathrm{TM}}$ membrane dryer is used for drying all samples upstream of the mass flow controller and sample loop. In the worst case design condition, the dryer is designed to reduce sample dew point to $0^{\circ} \mathrm{C}$ or lower. Although we have attempted by design to minimize the potential for condensation of water and or VOCs, we have no means for verifying that condensation does not occur. 


\subsubsection{Nafion ${ }^{T M}$ Dryer Design Layout}

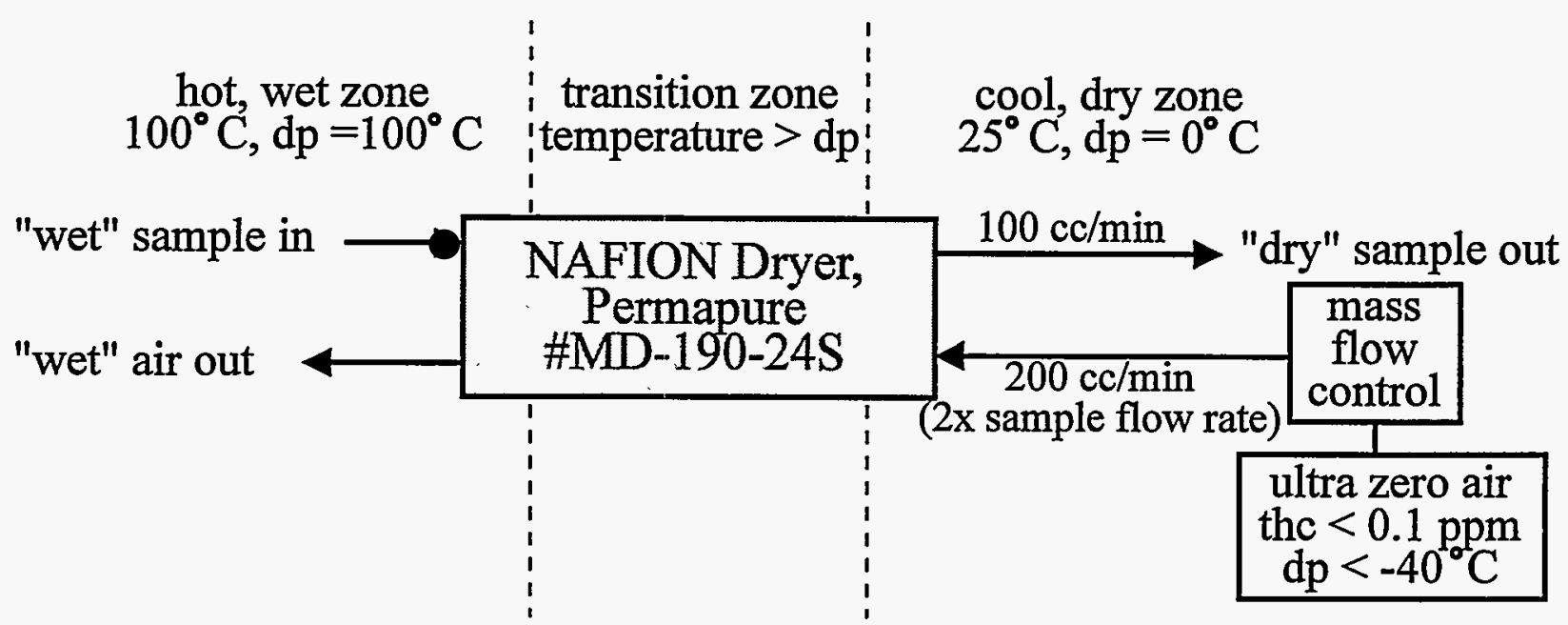

\subsubsection{Sample Loop Volume}

The sample loop size $(1 \mathrm{cc})$ was selected so that the concentration of any of the target analytes in a $1 \mathrm{cc}$ sample would fall within our target detection limits (10 ppm to $1,000 \mathrm{ppm})$ and also fall within the range bracketed by the FID minimum detection limit and the maximum column capacity.

Minimum sample volume is driven by the detection limit of the flame ionization detector (FID). The detection limit for the FID is conservatively estimated to be about 1 nanogram, although much less may be possible for some compounds.

Maximum sample volume is limited by the capacity of the column. The capacity of the $0.53 \mathrm{~mm}$ ID capillary column is conservatively estimated to be 1000 nanograms per component, but much more is probable for most compounds.

\subsubsection{Sample Rate}

A sample rate of $100 \mathrm{cc} / \mathrm{min}$ was chosen because it is

- low enough to keep pressure drops within reasonable limits

- high enough to eliminate errors due to diffusion

- high enough to keep purge times reasonably short.

\subsection{Gas Chromatograph}

The gas chromatograph (GC) is a Varian model CX3400 with the following features.

- wide bore capillary column (Restek MXT-vol), designed specifically for volatile organic compound separation.

- flame ionization detector (see below)

- programmable column temperature from ambient to $250^{\circ} \mathrm{C}$

- carrier gas = Helium

- makeup gas = Helium 
- $\quad$ FID fuel $=$ Hydrogen

The chromatographic method is described in section 3.4.

\subsubsection{Flame Ionization Detector}

A flame ionization detector (FID) was used because it is responsive to almost all organic compounds, and has more than enough sensitivity for the TEVES application. FID response is greatest to hydrocarbons and decreases with increased substitution of other elements. The FID has the advantages of a wide dynamic range $\left(10^{7}\right)$, low sensitivity to water and most inorganic compounds, and requires essentially no maintenance.

\subsection{Extraction Manifold and Subsurface Pressure Instrumentation}

In addition to performing its primary mission of quantifying VOCs by gas chromatography, our system also monitors a variety of other parameters needed to characterize the TEVES experiment. These include extraction manifold temperature, pressure, humidity, and flow rate, barometric pressure, and a variety of subsurface pressures. Manifold temperature and relative humidity are measured directly by a Vaisala HMP-235 humidity transmitter. Manifold flow rate is measured indirectly by an averaging pitot tube Omega \# FPT-6130. Manifold pressure, barometric pressure, and 12 subsurface pressures are measured by a customized pressure scanning system developed by Science Engineering Associates (SEA).

\subsubsection{Extraction Manifold \& Subsurface Pressure Instrumentation}

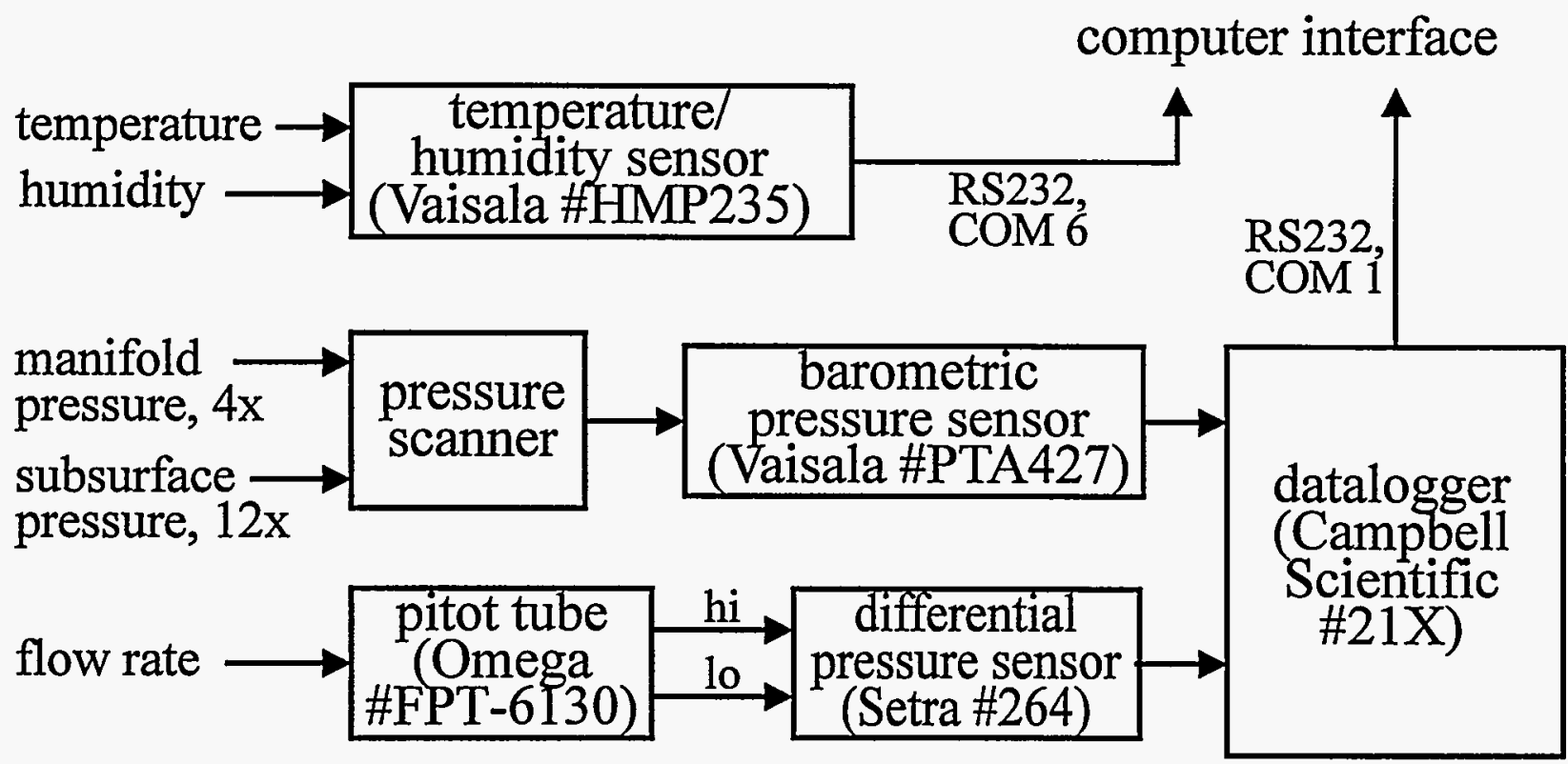

\subsection{Computer and Data Acquisition Hardware}

All system functions are controlled by a DEC model 466d2 MT computer. To run the software with acceptable response time a $66 \mathrm{MHz} 486$ with at least $16 \mathrm{MB}$ RAM is required. A National 
Instruments A/D board with signal conditioners and a Hostess 8 channel RS232 port board are used for data acquisition and control. Software is discussed in detail in Section 5.0.

\subsubsection{Computer \& Data Acquisition Hardware Block Diagram}

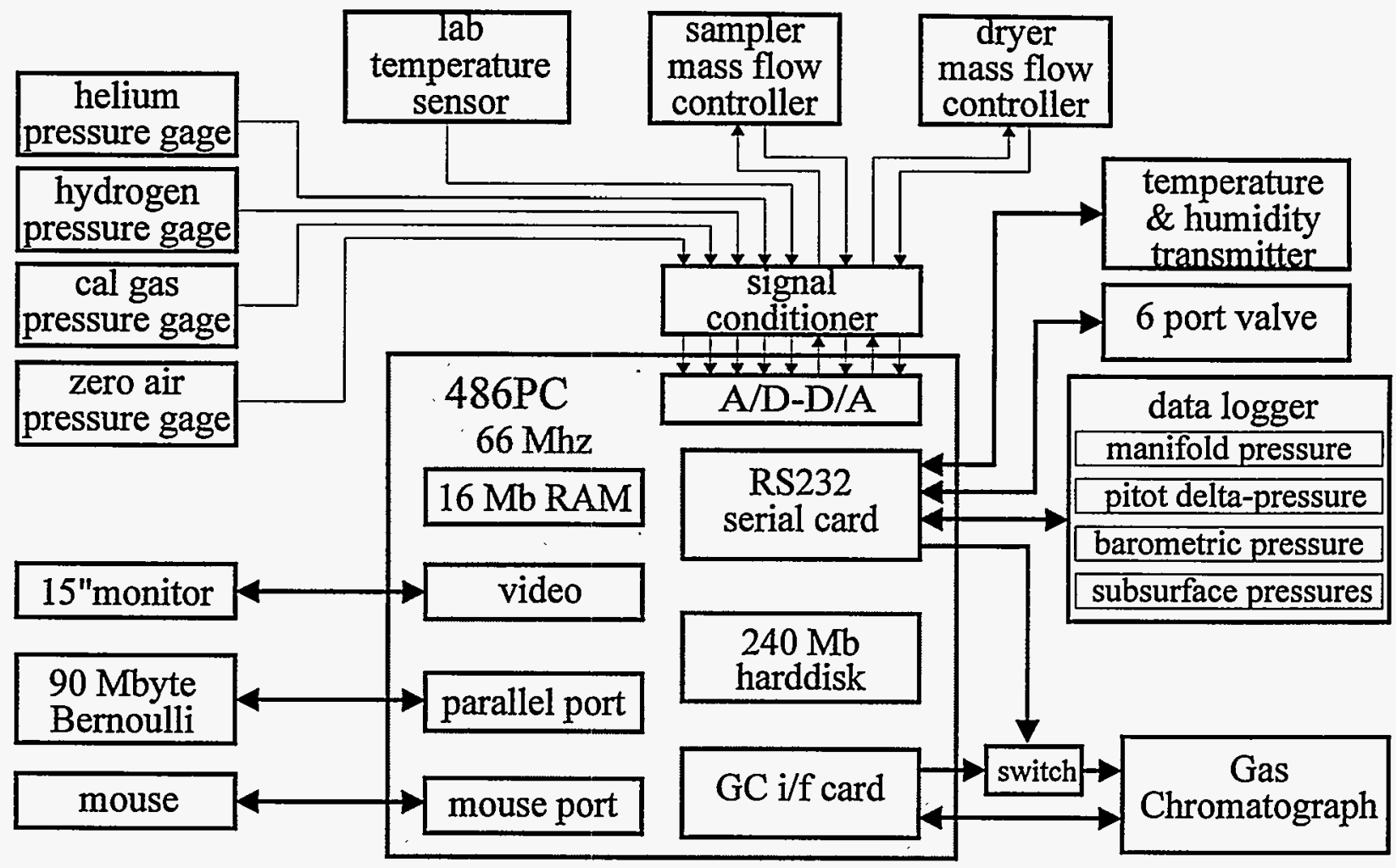




\subsubsection{Computer Electrical Interface}

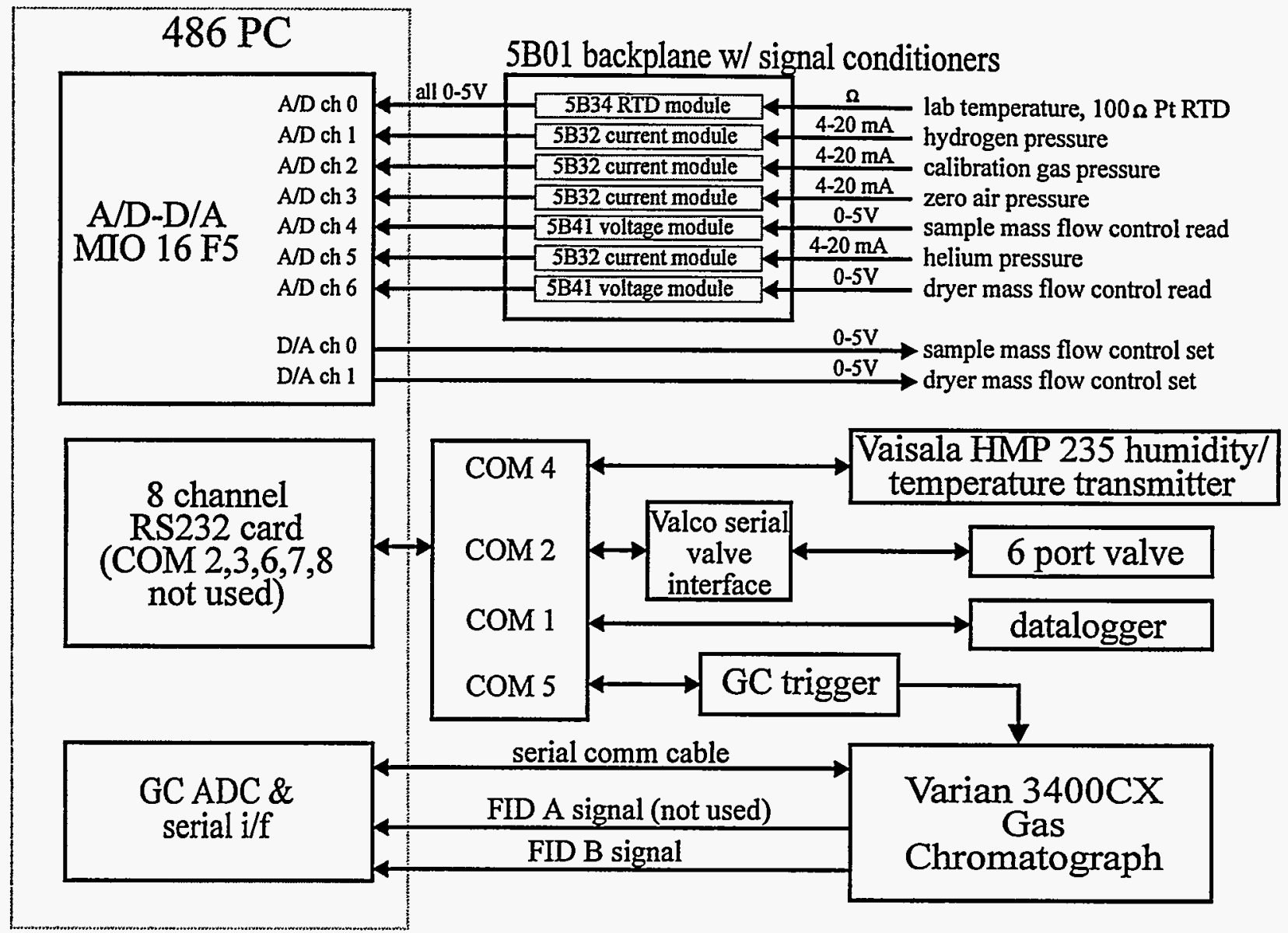

\subsection{Gas Supplies}

Five gases are used.

\begin{tabular}{|l|l|l|}
\hline Gas & purpose & source \\
\hline UHP Helium & carrier \& makeup gas for GC & cylinder \\
\hline UHP Hydrogen & FID fuel & cylinder \\
\hline Compressed Air & FID air & compressor \\
\hline UHP Zero Air & calibration blank \& NAFION drier & cylinder \\
\hline Calibration Gas & NIST-traceable calibration verification standard & cylinder \\
\hline
\end{tabular}

The GC back panel gas hookups are shown in Appendix B. Assembly diagrams for the helium, hydrogen, calibration gas, and zero air supplies are shown in Appendix C. The helium and hydrogen supplies are scrubbed prior to delivery to the GC by water/oxygen/hydrocarbon filters. Compressed air is supplied by an air compressor. All compressed gas cylinder pressures are monitored by the computer to ensure adequate gas supplies. Each manifold was leak tested using Snoop up to the pressure set point (100 psi) of the pressure relief valves. 


\subsection{Summary of Operation}

The autonomous GC system collects data to characterize several aspects of the TEVES experiment. The system operates continuously 24 hours a day, starting a new operating cycle (or task) every two hours. During each task, the following operations occur automatically:

- one of five vapor sources (calibration gas, zero air, extraction manifold, pre catalytic oxidation unit, post catalytic oxidation unit) is selected for sampling

- the sample is prepared for injection into the GC

- the sample is analyzed using a wide bore capillary gas chromatography and 9 specific analytes are quantified

- parameters that impact data quality (trailer temperature, gas supply pressures, valve states, sample flow rate) are monitored.

- extraction manifold physical conditions are monitored (temperature, pressure, relative humidity)

- the mass removal rates for VOCs and water are calculated

- a summary data file is generated. This is designed to be imported into an EXCEL spreadsheet which will provide a quick and easy platform for data analysis and presentation

- a backup copy of the TEVES subdirectory in made onto a Bernoulli disk.

\subsection{Installation and Turn-on}

Prior to unattended operation, the system needs several manual adjustments, described in detail in Appendix A. Subsequently, all operations run unattended under computer control. Software is discussed in Section 5.0.

\subsection{Unattended Operation}

Five types of tasks are performed each day. Each task follows the same procedure as any other task with one exception - the choice of sample source. There are five sample sources, three from the TEVES and two used for data quality control. A scheduler program calls one of the five tasks to execute starting at a given time of day according to the following schedule: 


\subsubsection{TEVES Sampling Schedule}

\begin{tabular}{|l|l|l|l|}
\hline time & task name & sample source & purpose \\
\hline $00: 00$ & cal gas & NIST-traceable cal gas & calibration verification \\
\hline $02: 00$ & zero air & $\begin{array}{l}\text { zero air } \\
(\mathrm{dp}<-40 \mathrm{C}, \mathrm{THC}<0.1 \mathrm{ppm})\end{array}$ & $\begin{array}{l}\text { establish lower detection limit } \\
\& \text { measure carryover }\end{array}$ \\
\hline $04: 00$ & manifold & extraction manifold & $\begin{array}{l}\text { quantify vapors in untreated } \\
\text { borehole effluent }\end{array}$ \\
\hline $06: 00$ & pre cat ox & after condenser & pre cat-ox value \\
\hline $08: 00$ & zero air & $\begin{array}{l}\text { zero air } \\
(\mathrm{dp}<-40 \mathrm{C}, \mathrm{THC}<0.1 \mathrm{ppm})\end{array}$ & establish lower detection limit \\
\hline $10: 00$ & post cat-ox & exhaust stack & destruction verification \\
\hline $12: 00$ & calibrate & NIST-traceable cal gas & calibration verification \\
\hline $14: 00$ & zero air & $\begin{array}{l}\text { zero air } \\
(\text { dp }<-40 \mathrm{C}, \mathrm{THC}<0.1 \mathrm{ppm})\end{array}$ & $\begin{array}{l}\text { establish lower detection limit } \\
\text { \& measure carryover }\end{array}$ \\
\hline $16: 00$ & manifold & extraction manifold & $\begin{array}{l}\text { quantify vapors in untreated } \\
\text { borehole effluent }\end{array}$ \\
\hline $18: 00$ & pre cat-ox & after condenser & pre cat-ox value \\
\hline $20: 00$ & zero air & $\begin{array}{l}\text { zero air } \\
(\text { dp }<-40 \mathrm{C}, \mathrm{THC}<0.1 \mathrm{ppm})\end{array}$ & establish lower detection limit \\
\hline $22: 00$ & post cat-ox & exhaust stack & destruction verification \\
\hline
\end{tabular}

The sequence of operation for a typical cycle is:

1. initialize valve positions, $\mathrm{GC}$ settings, sample flow rate

2. read lab temp, pressures, flow rate

3. select sample source

4. dry the sample

5. purge sample loop

6. inject sample

7. run chromatographic method to measure concentrations of target analytes

8. calculate VOC mass removal rate, water mass removal rate, manifold flow rate

9. integrate and archive data

\subsection{Chromatographic Method}

The chromatographic method uses a single wide-bore capillary column and flame ionization detection. The column is a Restek model MXT-VOL (30 meters long, $3.0 \mathrm{~mm}$ thick film, 0.53 $\mathrm{mm}$ ID) designed specifically for volatile organic compound separations. A chromatogram is generated by injecting the sample loop contents directly on column, then reading the FID output while the oven temperature is controlled to a specific temperature versus time profile. The profile was selected to resolve as many VOCs as possible given the following constraints:

- the GC does not have sub-ambient temperature capability

- only a single general purpose column is used

- cycle time must be 2 hours or less. 
After the heaviest identified compound (Dichlorobenzene) elutes from the column, the column is baked out to condition the column and to remove any unidentified heavy compounds that might otherwise carry over into the next chromatography cycle. This is incorporated into every run by ramping the column temperature to $200^{\circ} \mathrm{C}$ for a short period of time. A cool down period of approximately 35 minutes is required to allow the oven to return to its initial temperature after the bakeout. The trailer into which the $\mathrm{GC}$ is placed must be capable of maintaining the temperature less than $20^{\circ} \mathrm{C}$.

\subsubsection{Column Oven Temperature Profile}

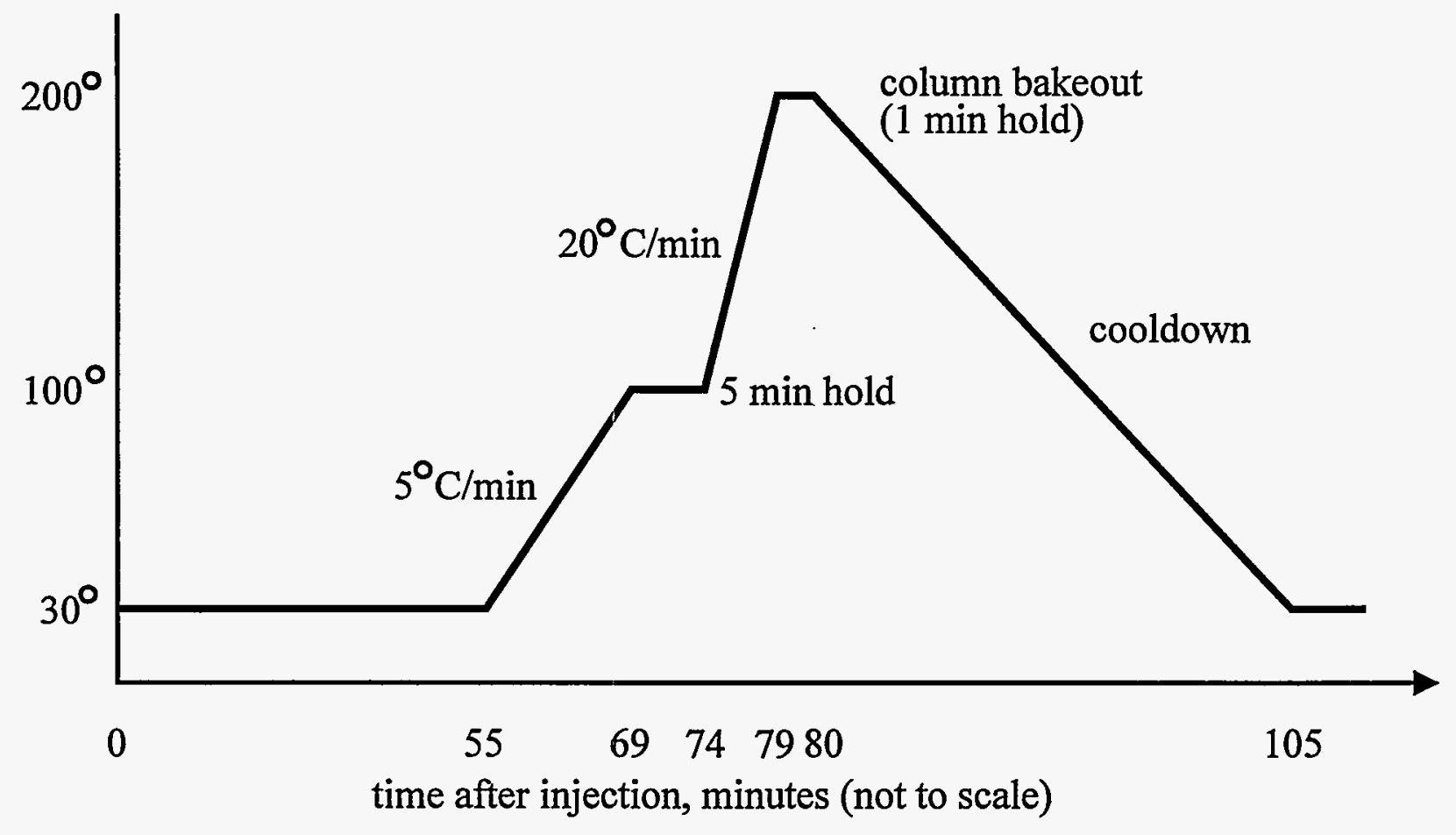

\subsubsection{GC gas flow rates}

The GC requires helium as a carrier and makeup, hydrogen and air for the FID. The flow rates are:

\begin{tabular}{|l|l|}
\hline Helium carrier & $7 \mathrm{cc} / \mathrm{min}$ \\
\hline Helium makeup & $20 \mathrm{cc} / \mathrm{min}$ \\
\hline FID Hydrogen & $30 \mathrm{cc} / \mathrm{min}$ \\
\hline FID air & $300 \mathrm{cc} / \mathrm{min}$ \\
\hline
\end{tabular}




\subsubsection{GC Results}

After a chromatogram is generated, retention time, peak area, and concentration of each compound are calculated by the Varian GC Applications software. A typical report is shown here:

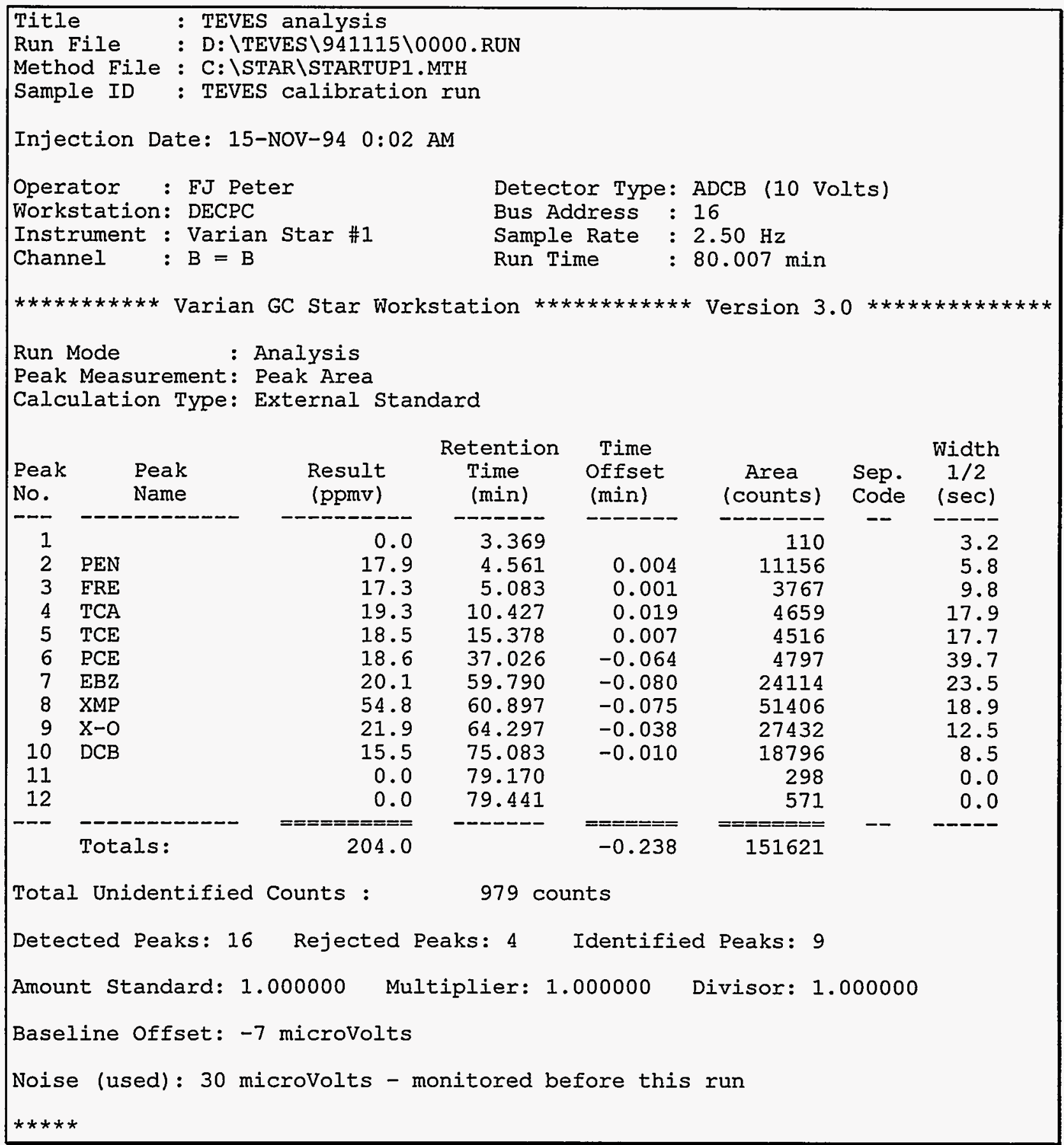




\subsection{Calibration \& Verification}

The relatively high expected concentrations (up to $1000 \mathrm{ppm}$ by volume) of some compounds places restrictions on unattended calibration of the GC. The problem is that compounds with low vapor pressures cannot be volatilized at even modest cylinder pressures (10s of $\mathrm{psi}$ ). The consequence is that calibration mixtures that bracket the high end of our concentration range of interest cannot be made in sufficient quantity, practically speaking, to support a long-term unattended application. For this reason, calibration and verification was divided into two groups: laboratory calibration and field verification.

\subsection{Laboratory Calibration}

All laboratory GC calibration runs were performed prior to the field tests and used the identical sampling procedure and hardware at the site. Multi-point calibrations $(0,2,20,200,1000 \mathrm{ppm}$ by volume) were performed in order of increasing concentrations with three replicates at each level for each compound. Absolute retention time on the column is used for compound identification and peak area is used for quantitation. All results are expressed as parts per million by volume (ppmv) at $20^{\circ} \mathrm{C}, 760 \mathrm{~mm} \mathrm{Hg}$. The calibration procedure and calculations are described in detail in Appendix D.

\subsection{Field Verification}

To ensure data quality, two types of quality control samples are taken. First, the calibration stability of the GC is verified on 12 hour intervals using a NIST-traceable gas standard (nominally $20 \mathrm{ppm}$ ) from Scott Specialty Gases. The certificate of analysis is given in Appendix E. Second, the lower detection limit is measured and carryover quantified by periodically analyzing zero air blanks. 


\subsection{Typical Calibration Chromatogram}

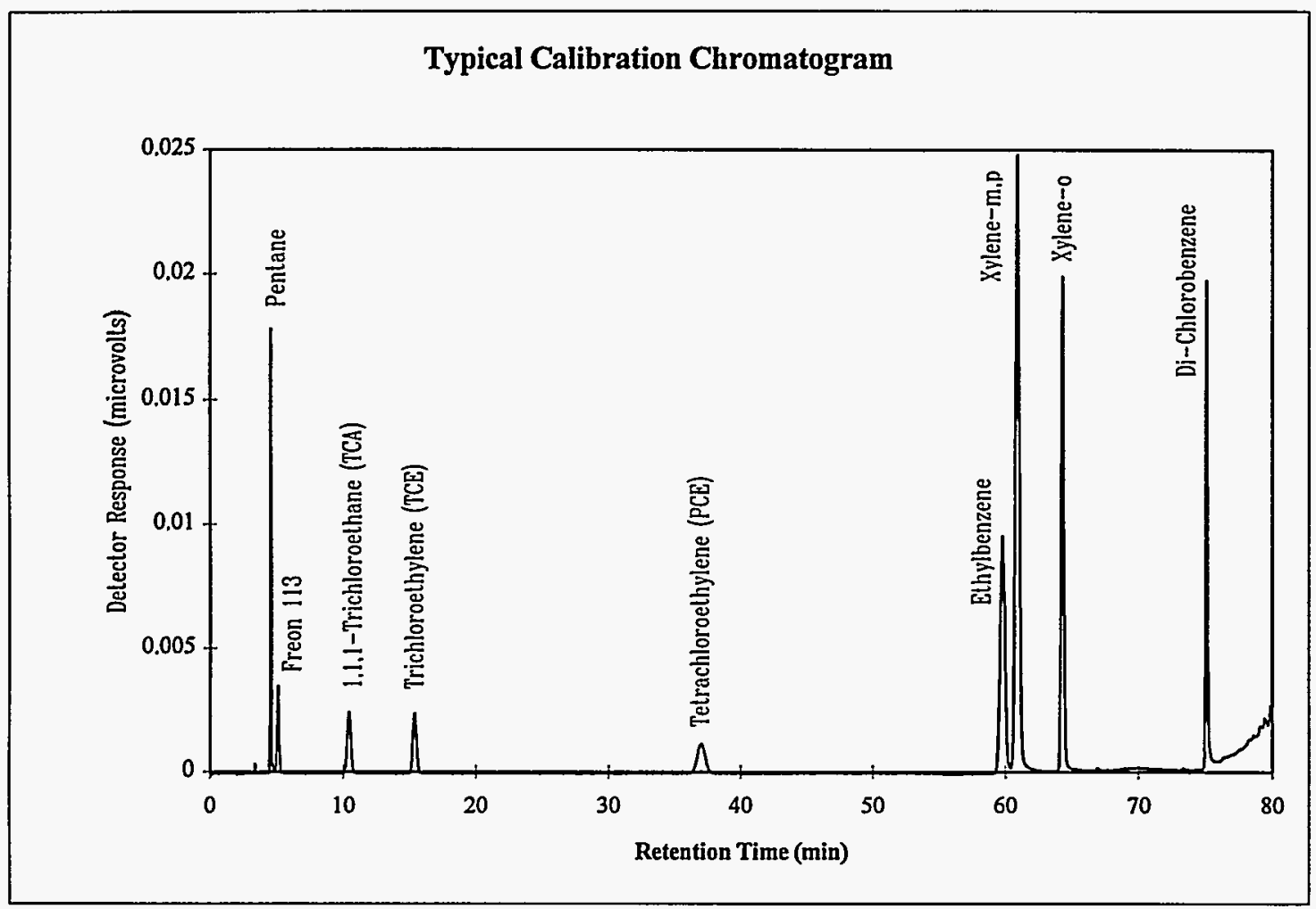




\subsection{Typical Calibration Report}

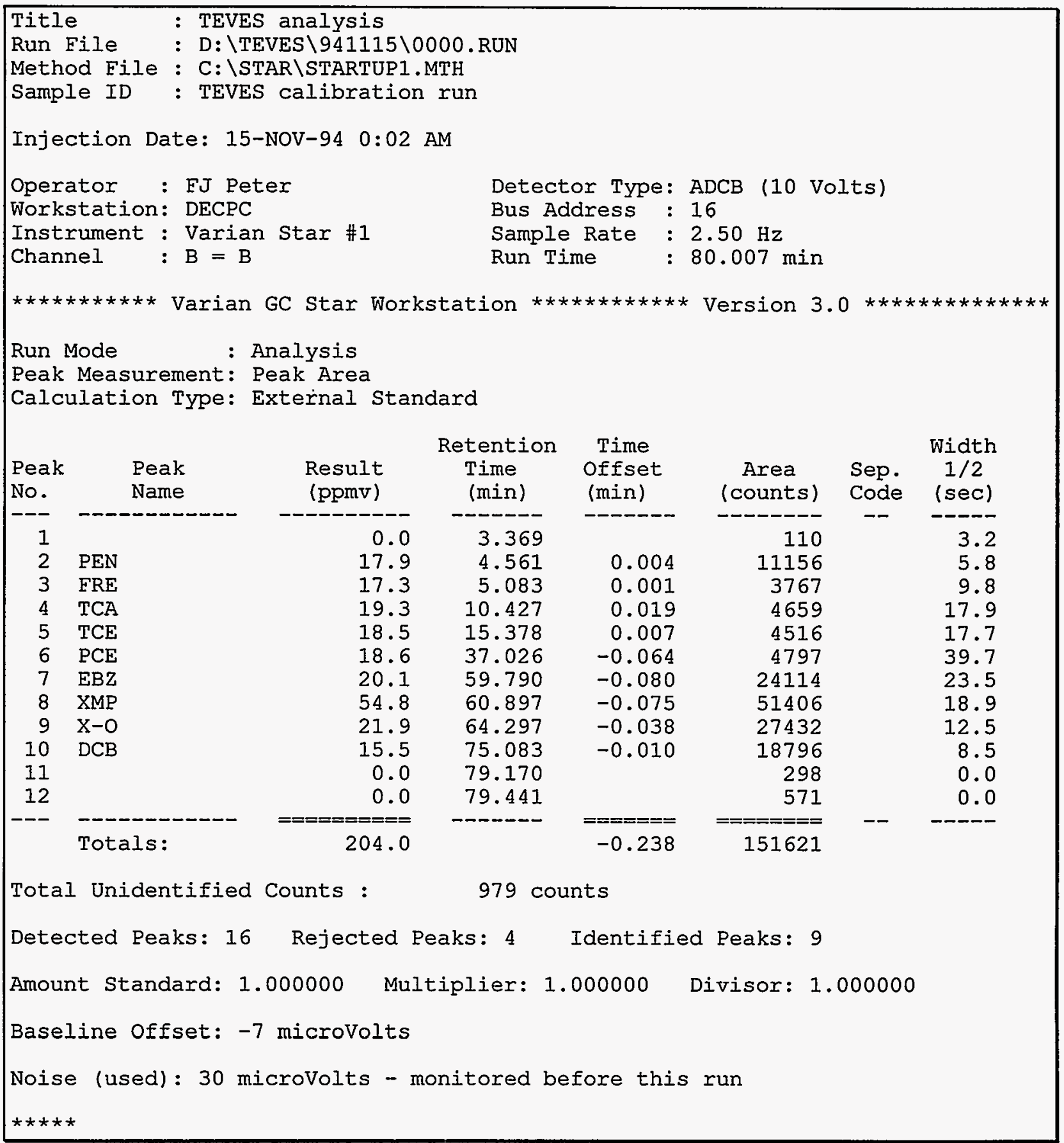




\subsection{Software}

The major software elements, all operating under Microsoft Windows, are:

1) Labview virtual instruments for instrument monitoring and control

2) the Varian GC Star Workstation software for controlling the GC method

3) several Visual Basic programs to provide timing synchronization between the Labview VIs and the Star Workstation and for creating the summary data file used by the EXCEL spreadsheet

4) an EXCEL spreadsheet for data manipulation and graphical presentation

\subsection{Software Architecture}

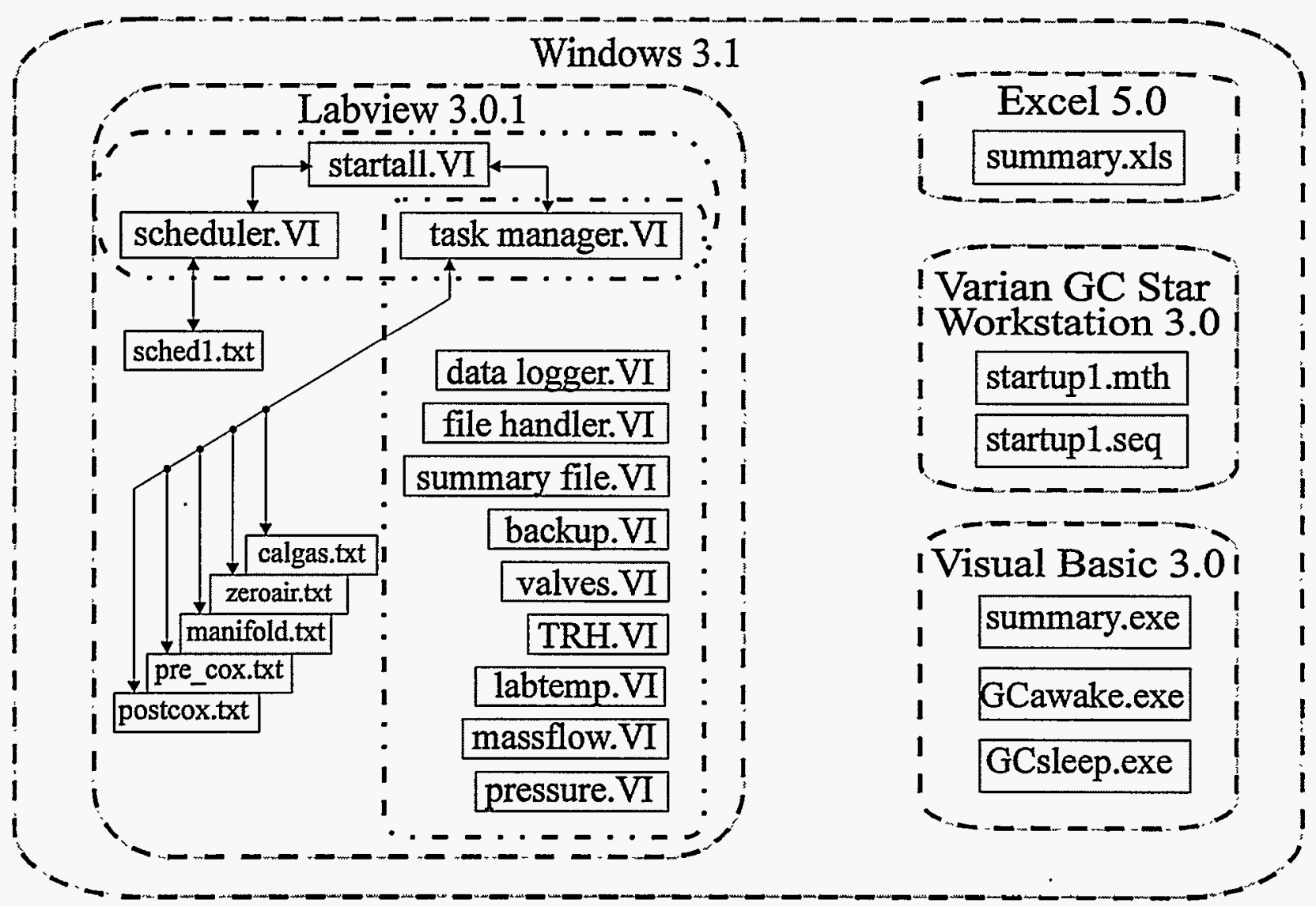

\subsubsection{Labview Virtual Instruments}

Most instrument control functions are written as Labview virtual instruments (VIs). All VIs and their respective functions are listed below: 


\begin{tabular}{|l|l|}
\hline virtual instrument name & description \\
\hline startall.VI & $\begin{array}{l}\text { starts the two main controlling VIs: } \\
\text { scheduler.VI \& task manager.VI. }\end{array}$ \\
\hline scheduler.VI & $\begin{array}{l}\text { reads a schedule file containing the time of day } \\
\text { based sequence files to pass to the task manager } \\
\text { and signals the task manager to begin sequence } \\
\text { execution. }\end{array}$ \\
\hline Task manager.VI & $\begin{array}{l}\text { triggers specific events (such as reading } \\
\text { temperatures, pressures, actuating valves) based } \\
\text { on times contained in task file. }\end{array}$ \\
\hline GC.VI & calls GC Star Workstation software \\
\hline H2P.VI & reads hydrogen gas cylinder pressure \\
\hline calgas.VI & reads calibration gas cylinder pressure \\
\hline carrier.VI & reads helium gas cylinder pressure \\
\hline TRH.VI & $\begin{array}{l}\text { reads the temperature and relative humidity from } \\
\text { the Vaisala instrument. }\end{array}$ \\
\hline RTD.VI & reads lab temperature \\
\hline mass flow controller.VI & $\begin{array}{l}\text { sets and reads sampler flow rate } \\
\text { \& zero air flow rate for Nafion }\end{array}$ \\
\hline valves.VI & $\begin{array}{l}\text { controls and reads position of Valco electrically } \\
\text { actuated valves }\end{array}$ \\
\hline datalogger.VI & reads and save datalogger data \\
\hline file handling.VI & names \& stores data files \\
\hline backup.VI & backup to 90 Mbyte Bernoulli disk \\
\hline
\end{tabular}

\subsubsection{GC Star Workstation Application}

The GC is controlled by the Varian Star Workstation. Functions include calibration, column oven temperature control, sample inject valve control, FID output measurement, chromatographic analysis, and report generation.

\subsubsection{Visual Basic Applications}

There are three Visual Basic applications:

\begin{tabular}{|l|l|}
\hline Gcawake.exe & opens and operates GC Star Workstation application \\
\hline GCsleep.exe & closes Star Workstation application \\
\hline summary.exe & $\begin{array}{l}\text { generates a comma delimited data file, yymmdd.CSV which } \\
\text { integrates all data files up to and including the given day into a } \\
\text { single ASCII text file for uses by an Excel spreadsheet }\end{array}$ \\
\hline
\end{tabular}

\subsubsection{EXCEL Spreadsheet}

The summary data files, yymmdd.CSV, contain all relevant TEVES data in a form directly importable to a customized EXCEL spreadsheet. The spreadsheet provides a single integrated platform for analysis and presentation of all TEVES data. TEVES data may be accessed at any 
time (up to the most recently completed operating cycle) by removing the Bernoulli disk used for backups and importing the summary data file into the EXCEL spreadsheet.

\subsection{Software Sequence of Operation}

After all the hardware (GC, data acquisition, sampling system, etc.) is turned on (see Appendix

A), the software can be run. The sequence of software operation is:

1. the machine boots from the hard disk wherein CONFIG.SYS is executed, AUTOEXEC.BAT is executed.

2. the STARTALL.VI program opens all Labview Virtual instruments

3. the scheduler.VI waits for the system clock to trigger the appropriate task files at the appropriate times.

4. the task manager.VI waits for the system clock to trigger the hardware and data collection events at the appropriate times.

5. the GC method runs

6. at the end of each task, a set of data files containing all data acquired during that task (instrument readings, raw chromatograms, datalogger data, etc.) is saved to hard disk.

7. a summary data file is updated on the hard disk

8. all data files are backed up to the Bernoulli disk

9. wait for next task

\subsection{Summary Data File}

The summary data file contains the following data:

- date/time of sample collection

- sample location (zero air, calibration gas, extraction manifold, cat-ox inlet, or cat-ox exhaust)

- extraction manifold temperature, pressure, relative humidity, and pitot tube pressure differential

- species concentration for each target analyte (in units of ppm by volume @ STP).

- GC state of health measurements

- data logger pressure scanner data

\subsection{Task Files}

For the TEVES project, there are five task files, one for each sample source:

\begin{tabular}{|l|l|}
\hline task file name & contains \\
\hline manifold.txt & Extraction Manifold sample sequence \\
\hline pre_cox.txt & Pre cat-ox sample sequence \\
\hline postcox.txt & Post cat-ox sample sequence \\
\hline calgas.txt & Calibration sequence \\
\hline zeroair.txt & Zero air sequence \\
\hline
\end{tabular}




\subsection{Data File and Data Directory Organization}

Each subdirectory named as yymmdd is intended to hold the data files (chromatograms and other instrumentation data files) for the day defined by the subdirectory name. The data file name format is hhmm.ext where hhmm represents military time. The ext is an extension identifying the contents of the datafile.

\begin{tabular}{|c|c|c|c|}
\hline Subdirectory Name & Filename(s) & file type & description \\
\hline $\mathrm{C}: \mathrm{I}$ & autoexec.bat & batch & set $\mathrm{PC}$ environment \\
\hline C:IDOS & DOS 6.2 files & see DOS manual & operating system \\
\hline C:IWINDOWS & Windows 3.1 files & $\begin{array}{l}\text { see Windows } \\
\text { manual }\end{array}$ & operating system \\
\hline C:ISTAR & Star files & see Star manual & GC control \\
\hline C:ILABVIEW & Labview files & $\begin{array}{l}\text { see Labview } \\
\text { manual }\end{array}$ & Labview application \\
\hline C:LLABVIEWTTEVES & *.VI & *.VI & Virtual instruments \\
\hline C:IVB & $\begin{array}{l}\text { GCawake.exe } \\
\text { GCsleep.exe } \\
\text { summary.exe }\end{array}$ & ${ }^{*}$. exe & $\begin{array}{l}\text { GC Star Workstation control } \\
\text { creates summary data file }\end{array}$ \\
\hline C:ITEVES & $\begin{array}{l}\text { sched1.txt } \\
\text { manifold.txt } \\
\text { pre_cox.txt } \\
\text { postcox.txt } \\
\text { calgas.txt } \\
\text { zeroair.txt } \\
\end{array}$ & ASCII text & $\begin{array}{l}\text { schedule file } \\
\text { manifold sample task file } \\
\text { pre cat-ox sample task file } \\
\text { post cat-ox sample task file } \\
\text { cal gas sample task file } \\
\text { zero air sample task file }\end{array}$ \\
\hline C:ITEVESlyymmdd & $\begin{array}{l}y y m m d d . C S V \\
\text { hhmm.RTD } \\
h \text { hmm.dat } \\
\text { hhmm.hep } \\
h \text { hmm.h2p } \\
\text { hhmm.cg } \\
\text { hhmm.TRH }\end{array}$ & ASCII text & $\begin{array}{l}\text { summary data thru current day } \\
\text { RTD temperature reading } \\
\text { chromatogram report } \\
\text { Helium pressure } \\
\text { Hydrogen pressure reading } \\
\text { cal gas pressure reading } \\
\text { manifold temperature \& ... } \\
\text {...relative humidity readings }\end{array}$ \\
\hline
\end{tabular}




\subsection{Lessons Learned, Proposed System Improvements}

\subsection{Hardware}

Sample Filtering. The mass flow controller on the post cat-ox sample line needed to be replaced several times because it was fouled by the "dirty" samples downstream of the cat-ox unit. A gravity trap for "heavy" particulates, followed by a graduated filter (multiple step, with finer filtering at each stage) is recommended.

Hydrogen Source. The compressed Hydrogen cylinder should be replaced by a Hydrogen Generator, which generates $\mathrm{H}_{2}$ from distilled water on demand. This has two benefits:

1. it would enhance fire safety by limiting the volume of stored hydrogen and by eliminating the possibility of introducing a leak during cylinder changeout.

2. there would be no need to interrupt testing to replace empty cylinders.

Air Compressor. The current compressor is extremely loud and has minimal storage tank volume. Investing in a quieter compressor with a larger storage tank would have two benefits:

1. a more comfortable work space by significantly reducing noise.

2. in the event of an electrical power blackout, the larger storage tank would reduce the risk of the FID flaming out due to lack of air flow.

\subsection{Software}

The system test schedule and methods are currently coded as text files. This requires that the user has some facility with a text editor and requires an understanding of the required text file syntax. A graphical user interface (GUI) schedule editor that insulates the user from the details is highly recommended if frequent changes in test schedule and methods are required. 


\section{Appendix A: System Installation \& Turn-on}

\section{Computer/Electrical System Turn-on}

1. make sure all equipment, pumps, computer, and instruments are plugged in

2. turn on power to all instruments

3. turn on the GC, press the RESET button

4. run software (see software section)

\section{Compressed Gas System Turn-on}

1. close all valves in the manifold

2. open valve at gas cylinder fully

3. make sure it is open by reading pressure gauge on inlet of regulator

4. adjust regulator output pressure settings ( $\pm 2 \mathrm{psi}$ ) to the following:

- helium: 80 psi

- hydrogen: $40 \mathrm{psi}$

- zero air: $10 \mathrm{psi}$

- cal gas: $10 \mathrm{psi}$

5. open all shut-off valves

6. at initial turn-on, the excess flow valve on the hydrogen tank will likely trip due to the initial surge of flow, requiring that it be reset. Reset it by simply pressing the red button.

7. leak check visually using "Snoop" leak detection fluid.

8. recheck pressure gauges for proper pressure and adjust regulator if necessary.

\section{Setting GC Flow Rates}

All gas flow rates were preset in the laboratory using a bubble flow meter. See the GC manual for instructions. The nominal flow rates are:

- helium carrier $=7 \mathrm{cc} / \mathrm{min}$

- helium makeup $=20 \mathrm{cc} / \mathrm{min}$

- hydrogen $=30 \mathrm{cc} / \mathrm{min}$ :

- FID air $=300 \mathrm{ml} / \mathrm{min}$ :

\section{Lighting Flame Ionization Detector}

1. make sure hydrogen and air flow rates are properly set

2. press Shift and Ignite $B$ on front panel of GC and hold for 5 seconds.

3. make sure FID is lit by holding a cool shiny object next to exhaust port of FID. If lit, moisture will condense on the object. If not, recheck gas supply and flow rate settings.

Important: If loss of electrical power occurs for more than a few minutes, the FID flame will go out because the air compressor will stop supplying air. Although the software will begin to run when power returns, the FID may need to be relit per above instructions. 


\section{Appendix B: Gas Supply Hookups (back panel of GC)}

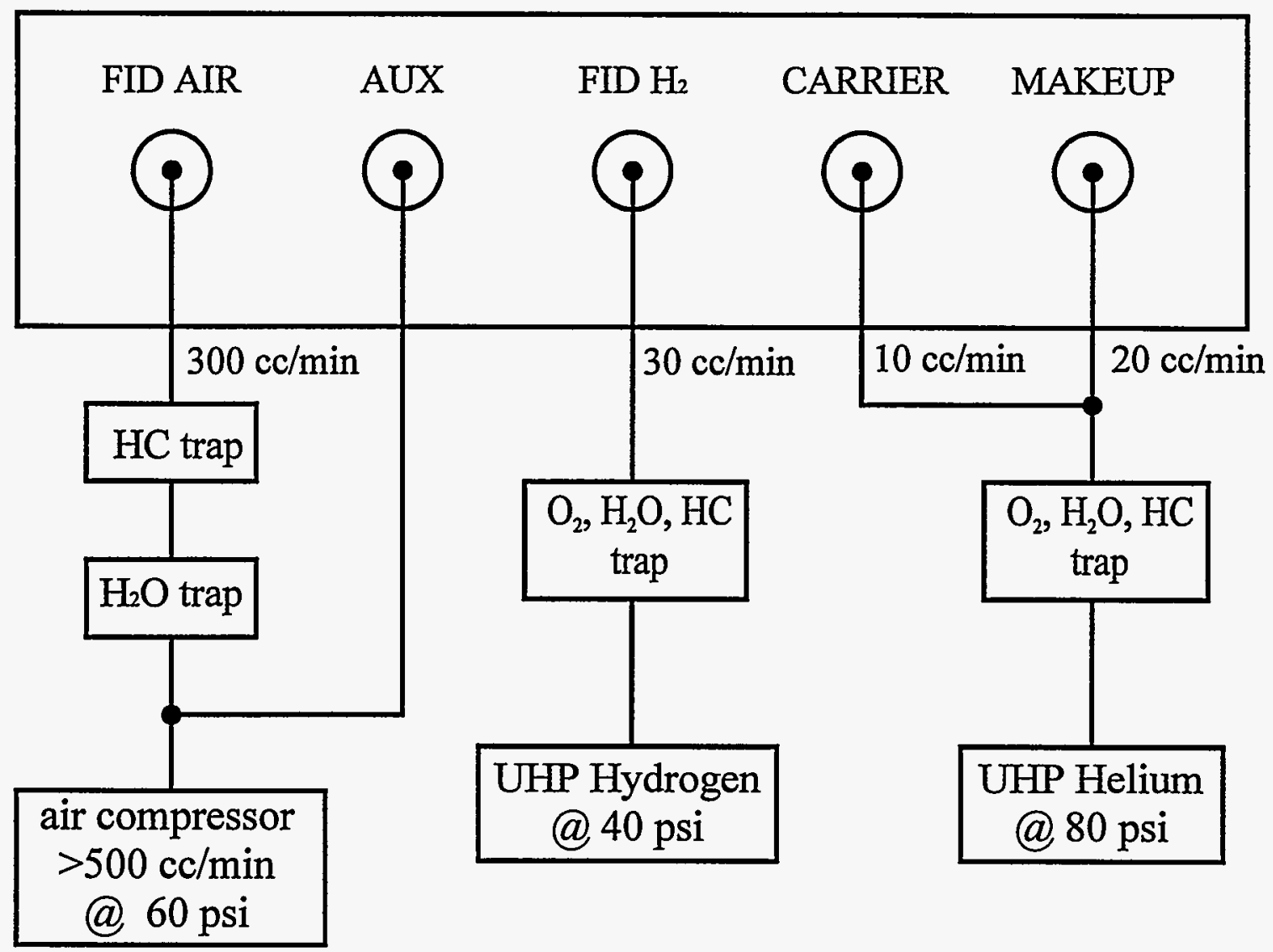




\section{Appendix C: Compressed Gas Assembly Diagrams}

\section{Helium}

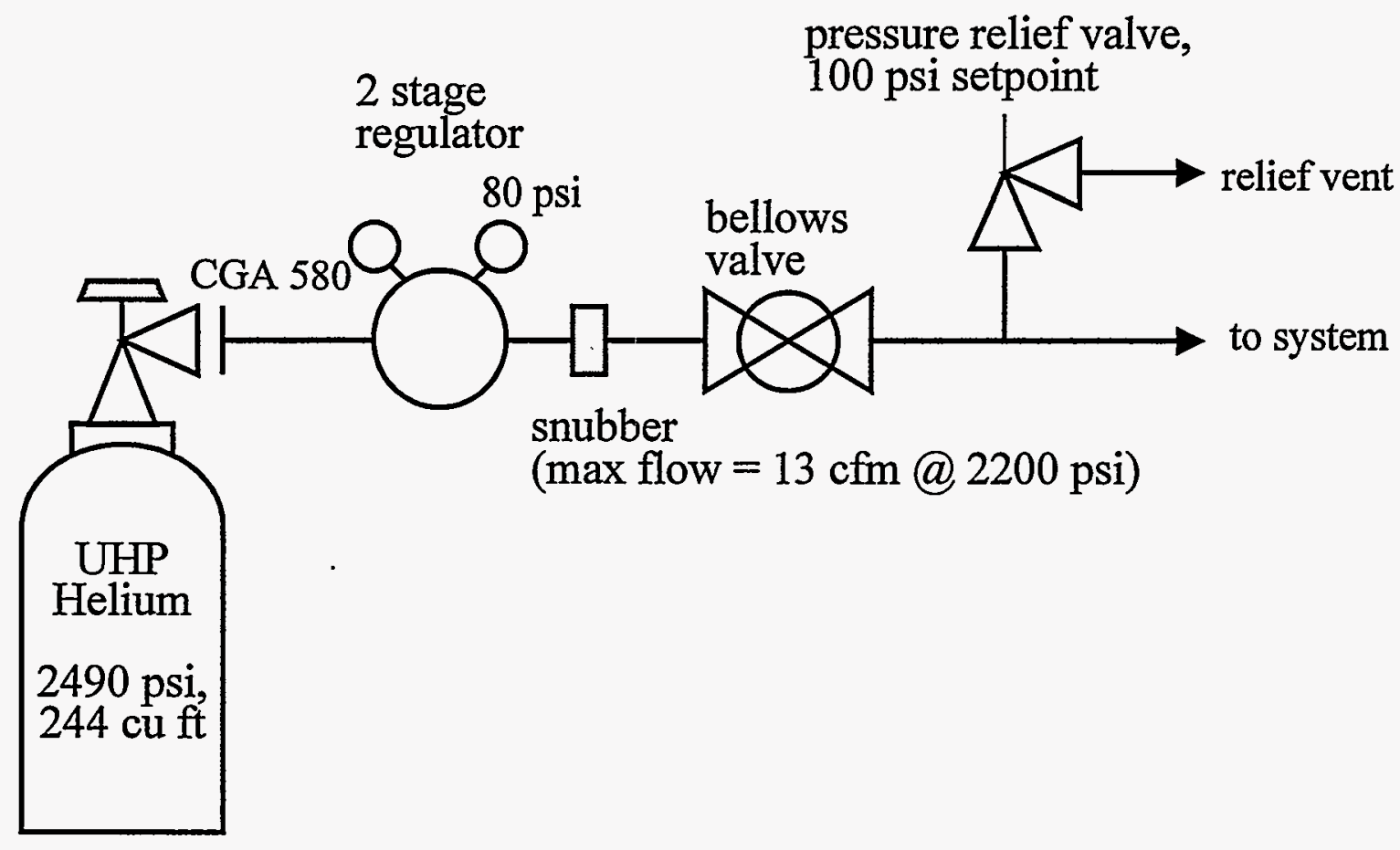

\section{Hydrogen}

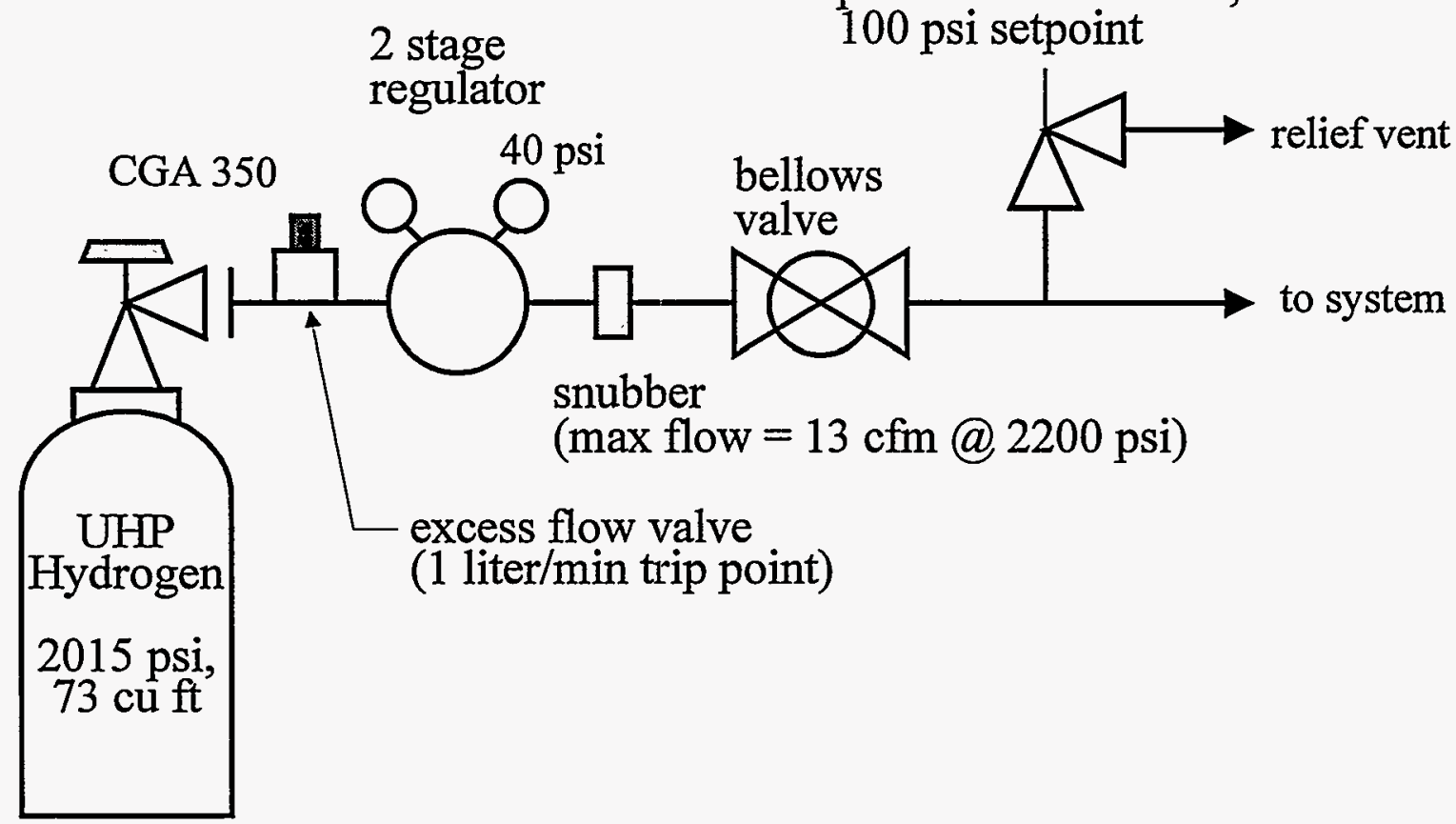




\section{Zero Air}

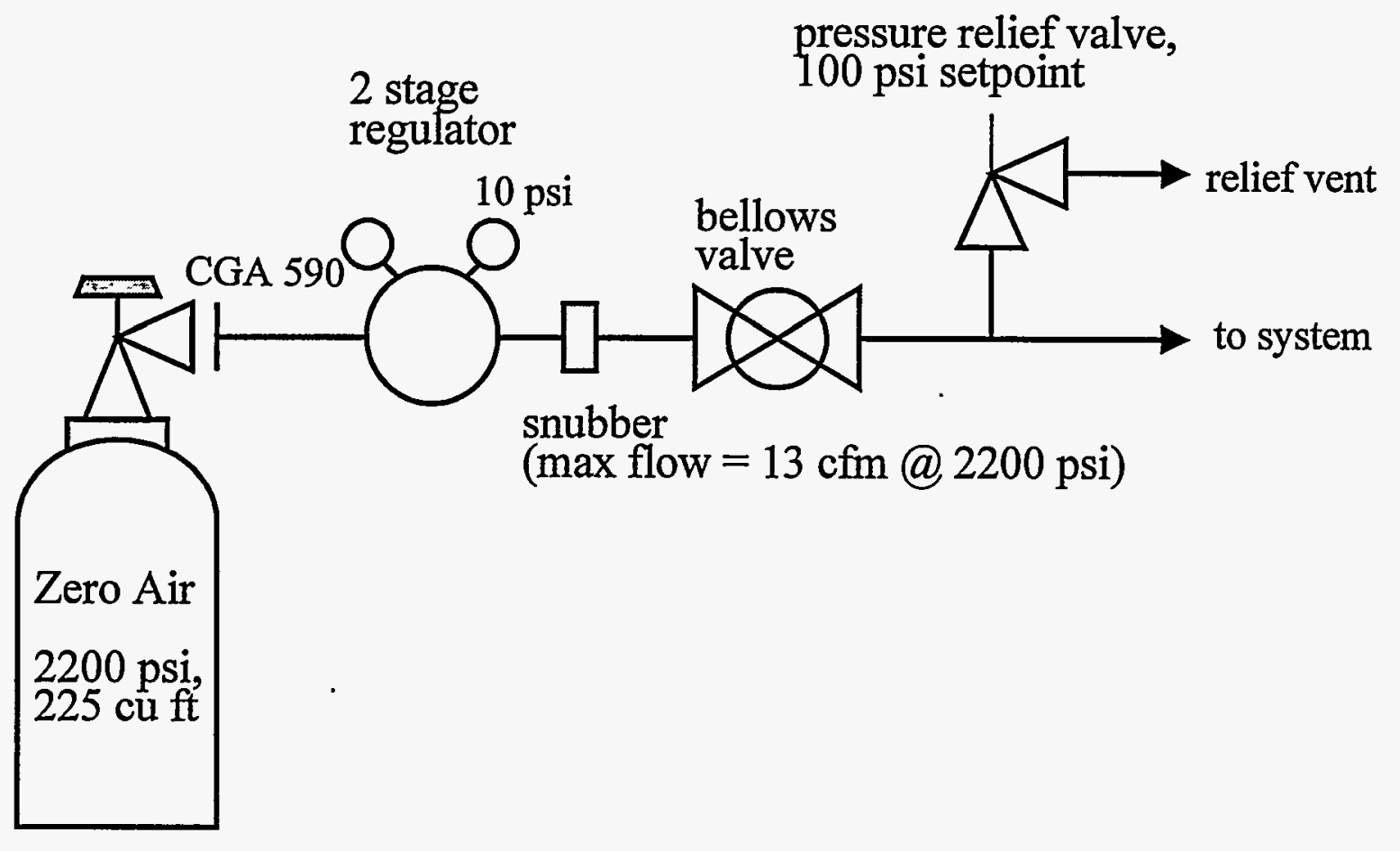

\section{Calibration Gas}

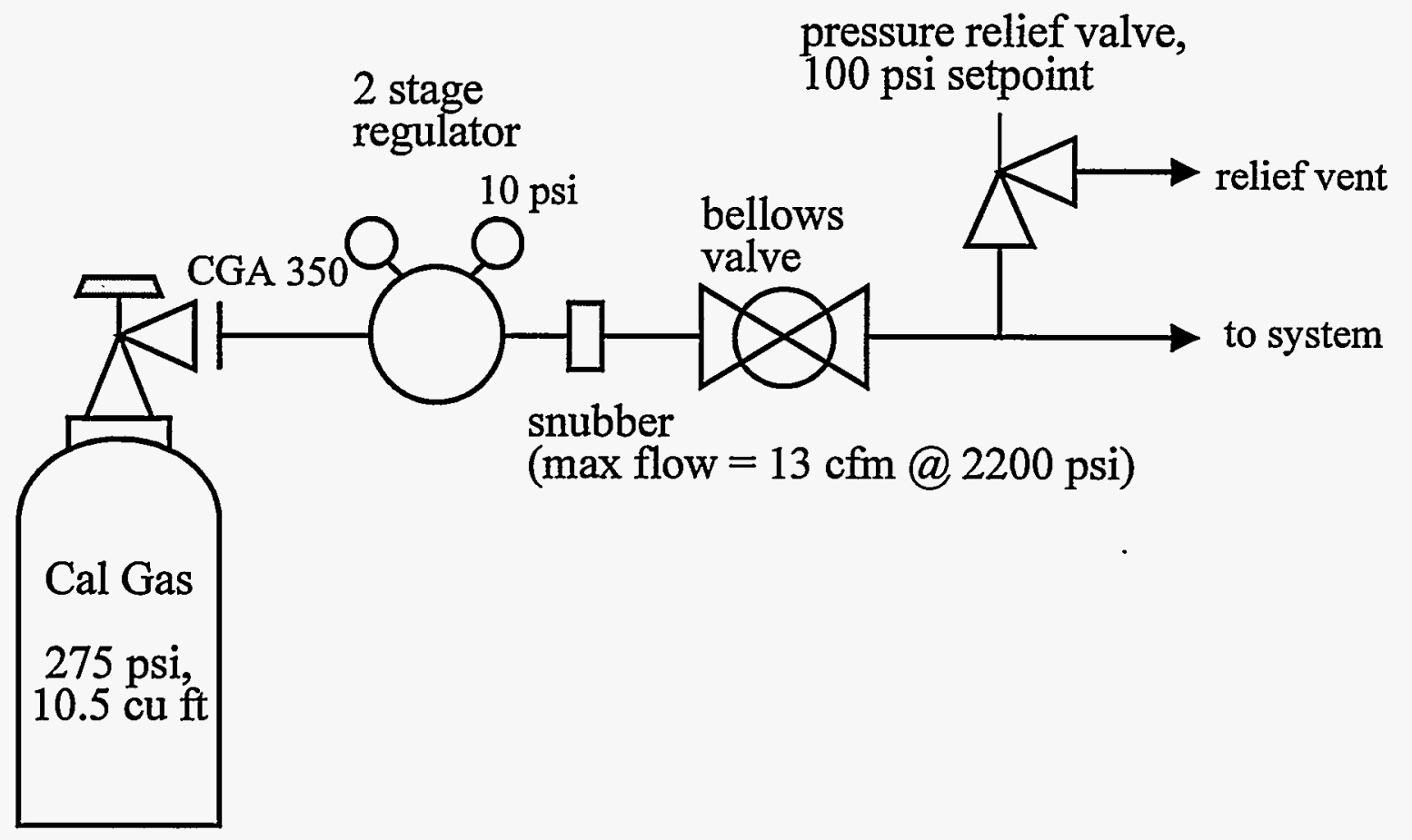




\section{Appendix D: Calibration}

\section{Calibration Standard Preparation}

Vapor phase calibration standards were prepared using the following procedure:

1. A Scott Specialty Gases Acculife aluminum cylinder (size $\mathrm{CL}$ ) was cleaned by purging with dry UHP Zero Air, then evacuated to $10^{-4}$ torr. This process was repeated three (3) times.

2. Each VOC of interest was introduced into the evacuated cylinder by injecting a measured volume of each through a silicone septum at the cylinder valve. A gas-tight microliter syringe was used to inject the compounds of interest, one at a time, in liquid phase. The syringe was cleaned between injections by purging twice with methanol and once with the VOC to be injected next.

3. After all compounds were injected, the cylinder was filled with a metered volume of UHP Zero Air using a precision mass flow controller. Flow rate was $500 \mathrm{cc} / \mathrm{min}$ and fill time was dependent on what volume of dilution gas was needed to achieve the desired VOC vapor concentration.

\section{Calculations}

All chromatographic results are calculated as parts per million by volume (ppmv) at $20^{\circ} \mathrm{C}, 760$ $\mathrm{mm} \mathrm{Hg}$. Vapor concentrations for each VOC are calculated as follows:

step 1) calculate mass injected: $\mathrm{m}_{\mathrm{X}}=\mathrm{V} \times \mathrm{r}_{\mathbf{X}}$

step 2) calculate volatilized vapor mass density: $d_{X}=m_{X} / V$

step 3) convert $\mathrm{mg} / \mathrm{m}^{3}$ to ppmv: $c_{\mathrm{X}}=\mathrm{d}_{\mathrm{X}} \times \mathrm{Z} / \mathrm{M}$

\begin{tabular}{|l|l|l|}
\hline$c_{\mathrm{X}}=$ & concentration of $\mathrm{x}$ & $\mathrm{ppmv}$ \\
\hline $\mathrm{d}_{\mathrm{X}}=$ & concentration of $\mathrm{x}$ & $\mathrm{mg} / \mathrm{m}^{3}$ \\
\hline $\mathrm{m}_{\mathrm{X}}=$ & mass injected & milligrams \\
\hline $\mathrm{v}=$ & liquid volume of VOC $\mathrm{x}$ injected & $\mathrm{mliter}$ \\
\hline $\mathrm{r}_{\mathrm{X}}=$ & liquid density of VOC $\mathrm{x}$ & $\mathrm{g} / \mathrm{ml}$ \\
\hline $\mathrm{V}=$ & volume of dilution gas (zero air) & cubic meters \\
\hline $\mathrm{Z}=$ & $\begin{array}{l}\text { molar volume of perfect gas @ } \\
20^{\circ} \mathrm{C}, 760 \mathrm{~mm} \mathrm{Hg}\end{array}$ & 24.04 liters $/$ mole \\
\hline $\mathrm{M}=$ & molecular weight of $\mathrm{x}$ & grams $/$ mole \\
\hline
\end{tabular}




\section{Calibration Table}

\begin{tabular}{|l|l|l|l|l|l|}
\hline Compound & $\begin{array}{l}\text { CAS } \\
\text { number. }\end{array}$ & $\begin{array}{l}\text { conc* } \\
\text { level 1 }\end{array}$ & $\begin{array}{l}\text { conc* } \\
\text { level 2 }\end{array}$ & $\begin{array}{l}\text { conc* } \\
\text { level 3 }\end{array}$ & $\begin{array}{l}\text { conc* } \\
\text { level 4 }\end{array}$ \\
\hline Dichlorobenzene (1,2-) & $95-50-1$ & 2.14 & 20.4 & 213.6 & ------ \\
\hline Ethyl benzene & $100-41-4$ & 1.96 & 20.2 & 196.3 & ----- \\
\hline Freon 113 & $76-13-1$ & 2.01 & 20.0 & 201.4 & 1007.2 \\
\hline Pentane & $109-66-0$ & 2.09 & 21.1 & 208.6 & 1042.9 \\
\hline Tetrachloroethene & $127-18-4$ & 2.35 & 19.6 & 234.8 & 1174.2 \\
\hline Trichloroethane (1,1,1-) & $71-55-6$ & 2.41 & 20.3 & 241.1 & 1205.6 \\
\hline Trichloroethylene & $79-01-6$ & 2.67 & 19.9 & 267.5 & 1337.5 \\
\hline Xylene (m-) & $108-38-3$ & 1.97 & 20.6 & 196.5 & ---- \\
\hline Xylene (o-) & $95-47-6$ & 1.97 & 19.8 & 197.0 & ----- \\
\hline Xylene (p-) & $106-42-3$ & 1.96 & 19.4 & 196.1 & ----- \\
\hline UHP Zero Air & n/a & balance & ----- & balance & balance \\
\hline UHP Nitrogen & n/a & ----- & balance & ----- & ----- \\
\hline
\end{tabular}

conc* $=$ ppm by volume @ $20^{\circ} \mathrm{C}, 760 \mathrm{~mm} \mathrm{Hg}$

Level 1: made by mixing 0.5 mliter liquid of each compound and 50 liters air Level 2: NIST-traceable standard from Scott Specialty Gases, Scott \#CAL9245

Level 3: made by mixing 10 mliter liquid of each compound and 10 liters air Level 4: made by mixing 50 mliter liquid of each compound and 10 liters air (compounds with VP $>10 \mathrm{~mm} \mathrm{Hg}$ ) 


\section{Appendix E: Calibration Standard Certificate of Analysis}

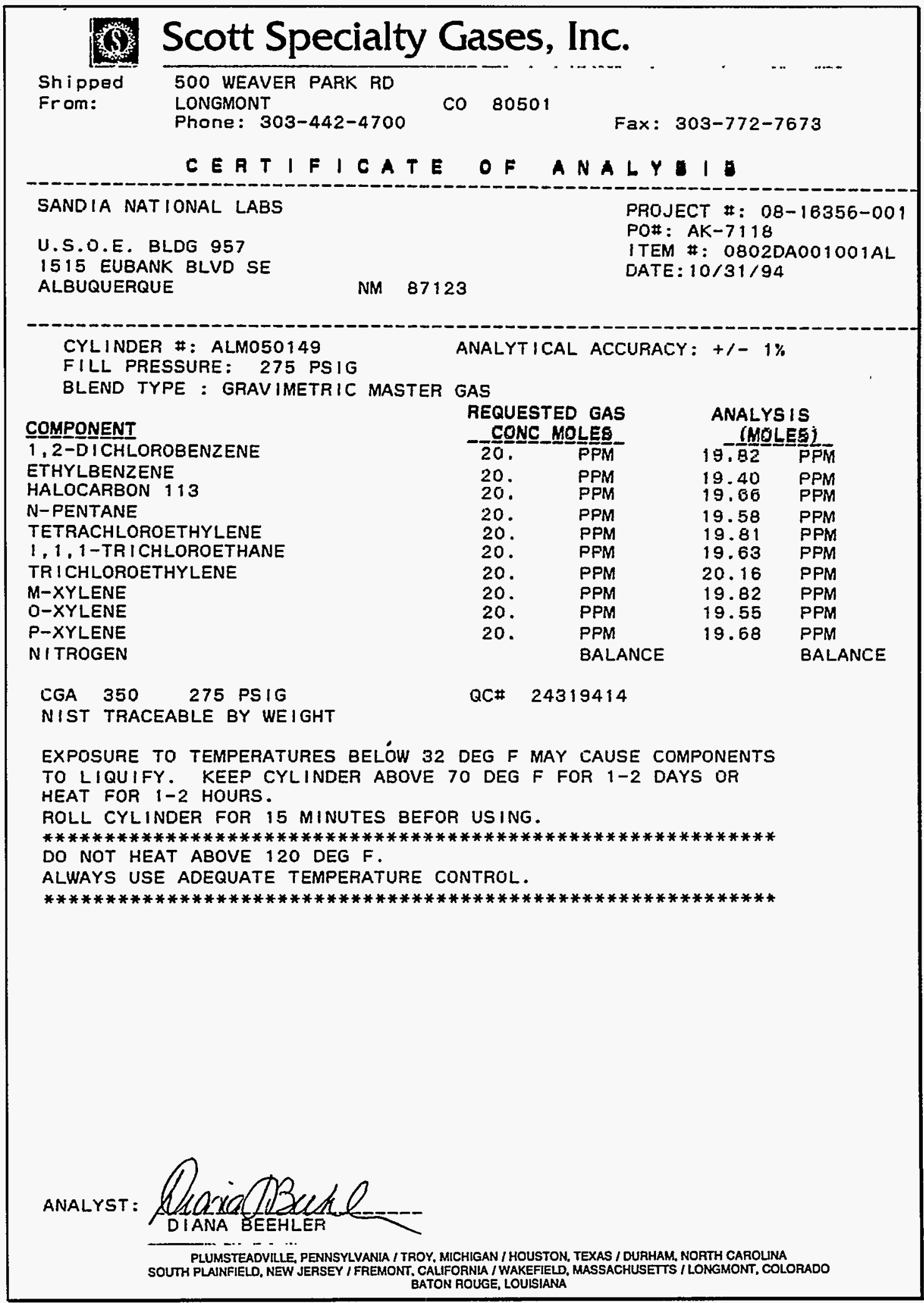




\section{Appendix F: Power Requirements}

All instruments operate using $120 \mathrm{VAC}$. The following is a conservative estimate of amperage required.

\begin{tabular}{|l|r|}
\hline Instrument & $\begin{array}{r}\text { Current } \\
\text { Amps }\end{array}$ \\
\hline Gas Chromatograph & 20.0 \\
\hline computer & 5.0 \\
\hline monitor & 1.5 \\
\hline Bernoulli drive & 1.0 \\
\hline A/D, digital I/O, etc & 2.0 \\
\hline valves & 1.0 \\
\hline mass flow controllers & 1.0 \\
\hline air compressor & 4.0 \\
\hline sample pump & 1.4 \\
\hline circulating pumps (2.0 A x 3 each) & 6.0 \\
\hline heated sample lines (3.6 A x 3 each) & 10.8 \\
\hline Total amperage estimate & $\mathbf{5 3 . 7}$ \\
\hline
\end{tabular}




\section{Appendix G: Routine Maintenance}

The only maintenance required is periodic replacement of compressed gases and gas filters. Cleaning of the FID electrode is not anticipated, but may be required if the samples are extremely dirty.

\section{Compressed Gas Replacement}

The helium, hydrogen, or zero air cylinders should be replaced when the tank pressure gauge reads 100 psi or less. Life expectancies for the gases are

\begin{tabular}{|l|l|l|l|}
\hline gas & quantity & $\begin{array}{l}\text { use rate } \\
\text { cc/min, duty cycle }\end{array}$ & lifetime \\
\hline hydrogen & $2015 \mathrm{psi}, 73 \mathrm{ft}^{3}$ & $30 \mathrm{cc} / \mathrm{min}, 100 \%$ & 40 days \\
\hline helium & $2000 \mathrm{psi}, 220 \mathrm{ft}^{3}$ & $30 \mathrm{cc} / \mathrm{min}, 100 \%$ & 66 days \\
\hline zero air & $2015 \mathrm{psi}, 225 \mathrm{ft}^{3}$ & $\begin{array}{l}10 \mathrm{cc}, 100 \% \\
200 \mathrm{cc} / \mathrm{min}, 4 \%\end{array}$ & 300 days \\
\hline cal gas & $275 \mathrm{psi}, 10 \mathrm{ft}^{3}$ & $100 \mathrm{cc} / \mathrm{min}, 0.002 \%$ & 150 days \\
\hline
\end{tabular}

\section{Gas Filters}

If the chromatogram baseline starts to look "dirty", the carrier gas filter should be replaced. Filter life expectancy with our system is expected to be many months of continuous usage.

\section{Particle Filters}

If a drop in sampler flow rate (as read by the sampler mass flow controller) takes place over time, the cause may be a clogged particle filter. If this is the case, the 2 micron stainless steel frit must be replaced.

\section{FID Detector Cleaning}

If a reduction in FID response is noticed over a period of time, as indicated by the twice daily field calibrations, it may be necessary to clean deposits from the FID electrode. See the GC manual for guidance on disassembly and cleaning. 


\section{Appendix H: Manifold air flow rate calculations}

Extraction manifold flow rate is calculated from three measurements:

- pitot tube differential pressure

- manifold static pressure

- manifold temperature

The calibration curve for the Omega \#FPT-6130 pitot tube is:

$Q=\sqrt{ }\left\{\begin{array}{c}16590 \times \mathrm{Dp} \times \mathrm{K}^{2} \times \mathrm{D}^{4} \times \mathrm{P} \\ \mathrm{s} \times(\mathrm{T}+460)\end{array}\right\}$

\begin{tabular}{|l|l|l|l|}
\hline $\mathrm{Q}=$ & flow rate & $\begin{array}{l}\mathrm{ft}^{3} / \mathrm{min} @ 60^{\circ} \mathrm{F}, 760 \\
\mathrm{~mm} \mathrm{Hg}\end{array}$ & (calculated) \\
\hline $\mathrm{Dp}=$ & differential pressure & inches $\mathrm{H}_{2} \mathrm{O}$ & (measured) \\
\hline $\mathrm{K}=$ & $\begin{array}{l}\text { pitot tube flow } \\
\text { coefficient }\end{array}$ & dimensionless & 0.665 (known) \\
\hline $\mathrm{D}=$ & pipe diameter & inches & 3 (known) \\
\hline $\mathrm{P}=$ & $\begin{array}{l}\text { manifold static } \\
\text { pressure }\end{array}$ & psi absolute & (measured) \\
\hline $\mathrm{s}=$ & specific gravity of air & relative to air @ $60^{\circ} \mathrm{F}$ & 1.0 (known) \\
\hline $\mathrm{T}=$ & temperature & ${ }^{\circ} \mathrm{F}$ & (measured) \\
\hline
\end{tabular}

To convert flow rate $\mathrm{Q}$ at $60^{\circ} \mathrm{F}\left(15.6^{\circ} \mathrm{C}=288.6 \mathrm{~K}\right)$ to flow rate $\mathrm{Q} \not \notin 20^{\circ} \mathrm{C}(293 \mathrm{~K})$ :

$$
\begin{aligned}
& Q^{\prime}=Q \times \frac{293}{288.6} \\
& Q^{\prime}=1.015 \times Q
\end{aligned}
$$




\section{Appendix I: VOC mass removal rate calculations}

VOC mass removal rate is simply the product of manifold air flow rate and mass density of VOC per volume air. It is calculated from two parameters:

- extraction manifold air flow rate $\mathrm{Q}^{\prime}$ (calculated per Appendix $\mathrm{H}$ )

- VOC concentration as measured by the GC

step 1) convert chromatographic result, parts per million by volume (ppmv) at $20^{\circ} \mathrm{C}, 760 \mathrm{~mm}$ $\mathrm{Hg}$ to $\mathrm{mg} / \mathrm{m}^{3}$ at $20^{\circ} \mathrm{C}, 760 \mathrm{~mm} \mathrm{Hg}$ for each VOC:

$D_{X}=C_{X} \times \underset{X}{-\frac{M_{X}}{Z}} \times \frac{273}{---} \times \frac{P}{---}$

\begin{tabular}{|l|l|l|}
\hline $\mathrm{C}_{\mathrm{X}}=$ & concentration of VOC $\mathrm{x}$ & $\mathrm{ppmv}$ \\
\hline $\mathrm{D}_{\mathrm{X}}=$ & concentration of VOC $\mathrm{x}$ & $\mathrm{mg} / \mathrm{m}^{3}$ \\
\hline $\mathrm{Z}=$ & $\begin{array}{l}\text { molar volume of perfect gas @ } 0^{\circ} \mathrm{C}, \\
760 \mathrm{~mm} \mathrm{Hg}\end{array}$ & 22.4 liters $/$ mole \\
\hline $\mathrm{M}_{\mathrm{X}}=$ & $\begin{array}{l}\text { molecular weight of } \\
\text { VOC } \mathrm{x}\end{array}$ & $\mathrm{grams} / \mathrm{mole}$ \\
\hline $\mathrm{T}=$ & local air temperature & ${ }^{\circ} \mathrm{K}$ \\
\hline $\mathrm{P}=$ & local air pressure & $\mathrm{mm} \mathrm{Hg}$ \\
\hline
\end{tabular}

At $20^{\circ} \mathrm{C}, 760 \mathrm{~mm} \mathrm{Hg}$, this reduces to:

$D_{X}=\frac{M_{X} \times C_{X}}{24.04}$

VOC mass removal rate converted to $\mathrm{lb} / \mathrm{hr}$ is:

$\mathrm{V}_{\mathrm{X}}=\mathrm{Q}^{\prime} \times \mathrm{D}_{\mathrm{X}} \times \underset{454,000 \mathrm{mg}}{-1 \mathrm{~b}} \frac{\mathrm{m}^{3}}{35.71 \mathrm{ft}^{3}} \mathrm{hr}$ 


\section{Appendix J: Water mass removal rate calculations}

Water mass removal rate is simply the product of manifold air flow rate and mass density of water per volume air. It is calculated from four parameters:

- extraction manifold air flow rate $\mathrm{Q}^{\prime}$ (calculated per Appendix $\mathrm{H}$ )

- manifold relative humidity (measured by Vaisala humidity transmitter)

- manifold temperature (also measured by Vaisala humidity transmitter)

- manifold pressure (measured by the pressure scanner)

Relative humidity is defined as the ratio of water vapor pressure to the saturation water vapor pressure at the gas temperature. Total pressure does not enter the definition.

step 1) calculate saturation water vapor pressure: Over the temperature range 0 to $200^{\circ} \mathrm{C}$, saturation water vapor pressure (psia) can be approximated ( $<0.38 \%$ error) by:

$\mathrm{P}_{\mathrm{ws}}=0.0885 \times 10(7.3354 \times \mathrm{T} /(230.5+\mathrm{T}))$

$\mathrm{T}=$ temperature, ${ }^{\circ} \mathrm{C}$

step 2) calculate water vapor concentration by volume: Water vapor concentration by volume is equivalent to the ratio of water vapor partial pressure to total (manifold) pressure.

$\mathrm{C}_{\mathrm{W}}=10^{6} \times(\mathrm{H} / 100) \times \mathrm{P}_{\mathrm{ws}} / \mathrm{P}_{\mathrm{t}}$

$\mathrm{C}_{\mathrm{W}}=$ water vapor concentration, $\mathrm{ppmv}$

$\mathrm{H}=$ relative humidity, $\%$

$\mathrm{P}_{\mathrm{ws}}=$ saturation water vapor pressure, $\mathrm{psia}$

$\mathrm{P}_{\mathrm{t}}=$ total (manifold) pressure, psia

step 3) convert ppmv to $\mathrm{mg} / \mathrm{m}^{3}$ at $20^{\circ} \mathrm{C}, 760 \mathrm{~mm} \mathrm{Hg}$ :

$D_{W}=C_{W} \times \frac{M_{W}}{Z} \times \frac{293}{-\frac{P}{T}} \times \frac{P}{760}$

\begin{tabular}{|l|l|l|}
\hline $\mathrm{C}_{\mathrm{W}}=$ & concentration of water & $\mathrm{ppmv}$ \\
\hline $\mathrm{D}_{\mathrm{W}}=$ & concentration of water & $\mathrm{mg} / \mathrm{m}^{3}$ air \\
\hline $\mathrm{Z}=$ & $\begin{array}{l}\text { molar volume of perfect gas } @ 20^{\circ} \mathrm{C}, \\
760 \mathrm{~mm} \mathrm{Hg}\end{array}$ & 24.04 liters $/$ mole \\
\hline $\mathrm{M}_{\mathrm{W}}=$ & molecular weight of water & 18.02 grams $/$ mole \\
\hline $\mathrm{T}=$ & manifold temperature & $\mathrm{K}$ \\
\hline $\mathrm{P}=$ & manifold pressure & $\mathrm{mm} \mathrm{Hg}$ \\
\hline
\end{tabular}


step 4) convert water mass removal rate to $\mathrm{lb} / \mathrm{hr}$ :

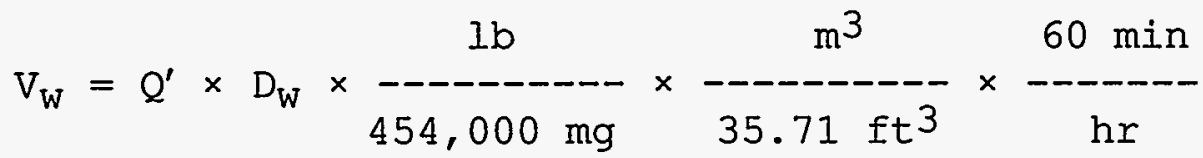




\section{Appendix K: Parts List (arranged by subsystem)}

\section{Chromatograph}

\begin{tabular}{|l|l|l|}
\hline \multicolumn{1}{|c|}{ description } & \multicolumn{1}{c|}{ supplier } & \multicolumn{1}{c|}{ part number } \\
\hline gas chromatograph & Varian & CX3400 \\
\hline FID & Varian & comes with above \\
\hline interface card for above & Varian & comes with above \\
\hline $\begin{array}{l}\text { wide bore capillary column, 30 meters } \\
\text { long, } 3.0 \mathrm{~mm} \text { thick fil, } 0.53 \mathrm{~mm} \text { ID }\end{array}$ & Restek & MXT-VOL \\
\hline liquid calibration standards, $1 \mathrm{ml}$ each & Accu-standard & custom order \\
\hline
\end{tabular}

\section{Sample Transfer Subsystem}

\begin{tabular}{|l|l|l|}
\hline \multicolumn{1}{|c|}{ description } & \multicolumn{1}{c|}{ supplier } & \multicolumn{1}{c|}{ part number } \\
\hline heated sampling line, Teflon, 25 ft long & Technical Heaters & $212-4-25$ \\
\hline diaphragm air pump, 1.1 cfm, 120 VAC & Fisher Scientific & $13-875-226$ \\
\hline particle filter, 90 mm SS frit & Nupro & SS-4TF-90 \\
\hline
\end{tabular}

\section{Sampler}

\begin{tabular}{|l|l|l|}
\hline \multicolumn{1}{|c|}{ description } & \multicolumn{1}{c|}{ supplier } & \multicolumn{1}{c|}{ part number } \\
\hline 6 port valve, electrically actuated & Valco & ESF6P \\
\hline RS232 Serial valve interface, for above & Valco & SVI \\
\hline sample loop, $1 \mathrm{cc}$ & Valco & SL1KC10UW \\
\hline Nafion Dryer & Perma-pure & MD-190-24S \\
\hline mass flow controller & Tylan & FC-260 \\
\hline readout box for above & Tylan & RO-28 \\
\hline rotary vane air pump, 1.5 cfm, 120 VAC & Thomas & SR-0015-VP \\
\hline
\end{tabular}

\section{Manifold Instrumentation}

\begin{tabular}{|l|l|l|}
\hline \multicolumn{1}{|c|}{ description } & \multicolumn{1}{c|}{ supplier } & \multicolumn{1}{c|}{ part number } \\
\hline Humidity/Temperature transmitter & Vaisala & HMP235 \\
\hline Platinum RTD $(100 \mathrm{~W})$ & Omega & PR-13-2-100-1/8-6-E \\
\hline data logger & Campbell Scientific & $21 \mathrm{X}$ \\
\hline pitot tube & Omega & FPT-6130 \\
\hline differential pressure sensor $\left( \pm 5^{\prime \prime} \mathrm{H}_{2} 0\right)$ & Setra & 264 \\
\hline
\end{tabular}




\section{Compressed Gases \& Plumbing}

\begin{tabular}{|l|l|l|}
\hline \multicolumn{1}{|c|}{ description } & \multicolumn{1}{|c|}{ supplier } & \multicolumn{1}{c|}{ part number } \\
\hline UHP Helium & Tri-Gas & SGUHPHE243M \\
\hline UHP Hydrogen & Tri-Gas & SGUHPHY73M \\
\hline UHP Zero air & Tri-Gas & SGUZCA239M \\
\hline Calibration Verification Standard & Scott Specialty Gases & Cylinder \#ALM050149 \\
\hline $\begin{array}{l}\text { pressure transmitter, 0-2500 psig, } \\
\text { 4-20 mA output }\end{array}$ & PSI-tronix & PG-4/20 \\
\hline $\begin{array}{l}\text { excess flow valve, CGA 350, } \\
1 \text { liter/min trip point }\end{array}$ & ABQ V\&F & 6L-E4-HA-350-VR4 \\
\hline pressure regulator & Concoa & 432-3301 \\
\hline shut off valve, metal bellows type & ABQ V\&F & SS-4BG-V51 \\
\hline pressure relief valve, 100 psi & ABQ V\&F & SS-RL3M4-S4-MO-100 \\
\hline gas purifier cartridge & Alltech & 81012 \\
\hline air compressor, $0.6 \mathrm{cfm}$ @ 60 psi & Thomas & LGH-210 \\
\hline
\end{tabular}

\section{Computer \& Data Acquisition Hardware}

\begin{tabular}{|l|l|l|}
\hline \multicolumn{1}{|c|}{ description } & \multicolumn{1}{c|}{ supplier } & \multicolumn{1}{c|}{ part number } \\
\hline computer, 80486, 66 MHz, 16 Mb RAM & DEC & 466d2 MT \\
\hline 15 ' monitor & DEC & PCXBV-DE \\
\hline RS232, 8 channel expander & Hostess & INHX0835A \\
\hline Bernoulli drive, 90 Mb & Liberty & 90PRO \\
\hline A/D, D/A I/O board & National Instruments & ADFIO16 \\
\hline 16 channel back plane & National Instruments & 5B01 \\
\hline RTD to 5 volt module & National Instruments & 5B34 \\
\hline \pm 5 V to 5 volt module & National Instruments & 5B41 \\
\hline $4 / 20$ ma to 5 volt module & National Instruments & 5B32 \\
\hline
\end{tabular}

